\title{
Current concepts and challenges to unravel the role of iodothyronine deiodinases in human neoplasias
}

\author{
luri Martin Goemann', Vicente Rodrigues Marczyk¹, Mirian Romitti², Simone Magagnin Wajner ${ }^{1}$ and \\ Ana Luiza Maia'
}

1Thyroid Unit, Endocrine Division, Hospital de Clínicas de Porto Alegre, Universidade Federal do Rio Grande do Sul, Porto Alegre, Rio Grande do Sul, Brazil

${ }^{2}$ Institut de Recherche Interdisciplinaire en Biologie Humaine et Moléculaire, Université Libre de Bruxelles, Brussels, Belgium

Correspondence should be addressed to A L Maia: almaia@ufrgs.br

\begin{abstract}
Thyroid hormones (THs) are essential for the regulation of several metabolic processes and the energy consumption of the organism. Their action is exerted primarily through interaction with nuclear receptors controlling the transcription of thyroid hormoneresponsive genes. Proper regulation of TH levels in different tissues is extremely important for the equilibrium between normal cellular proliferation and differentiation. The iodothyronine deiodinases types 1, 2 and 3 are key enzymes that perform activation and inactivation of THs, thus controlling TH homeostasis in a cell-specific manner. As THs seem to exert their effects in all hallmarks of the neoplastic process, dysregulation of deiodinases in the tumoral context can be critical to the neoplastic development. Here, we aim at reviewing the deiodinases expression in different neoplasias and exploit the mechanisms by which they play an essential role in human carcinogenesis. TH modulation by deiodinases and other classical pathways may represent important targets with the potential to oppose the neoplastic process.
\end{abstract}

\author{
Key Words \\ - iodothyronine deiodinases \\ - neoplasia \\ - carcinogenesis \\ - thyroid hormones
}

\section{Introduction}

Thyroid hormones (THs) are essential modulators of several physiological processes, including organ development, cell differentiation and tissue growth. Since the description of 3,3',5-triiodothyronine $\left(\mathrm{T}_{3}\right)$ in human plasma by Gross and Pitt-Rivers (1952), numerous studies have demonstrated that it is mainly derived from the peripheral deiodination of 3,3',5,5'-tetraiodothyronine or thyroxine $\left(\mathrm{T}_{4}\right)$ (Braverman et al. 1970, Sterling et al. 1970). Monodeiodination of $\mathrm{T}_{4}$ yields $\mathrm{T}_{3}$ by enzymatic outer ring deiodination (ORD) of $\mathrm{T}_{4}$ in the peripheral tissues such as the liver and the kidney, whereas the inactive form 3,3', $5^{\prime}$-triiodothyronine (reverse triiodothyronine, $\mathrm{rT}_{3}$ ) is formed by inner ring deiodination (IRD) (Fig. 1). Both triiodothyronines are further degraded by a cascade of deiodination steps (Braverman et al. 1970, Sakurada et al. 1978, Visser 1979).

Despite an initial hypothesis that sequential deiodination was performed by two distinct enzymes acting either in the phenolic or the tyrosyl ring, evidence soon demonstrated that a single enzyme, type 1 deiodinase (DIO1, DIO1), was responsible for both ORD and IRD (Fekkes et al. 1982, St Germain \& Morganelli 1989, Mandel et al. 1992). This process was classically studied in the liver, kidney and the thyroid and was subjected to 


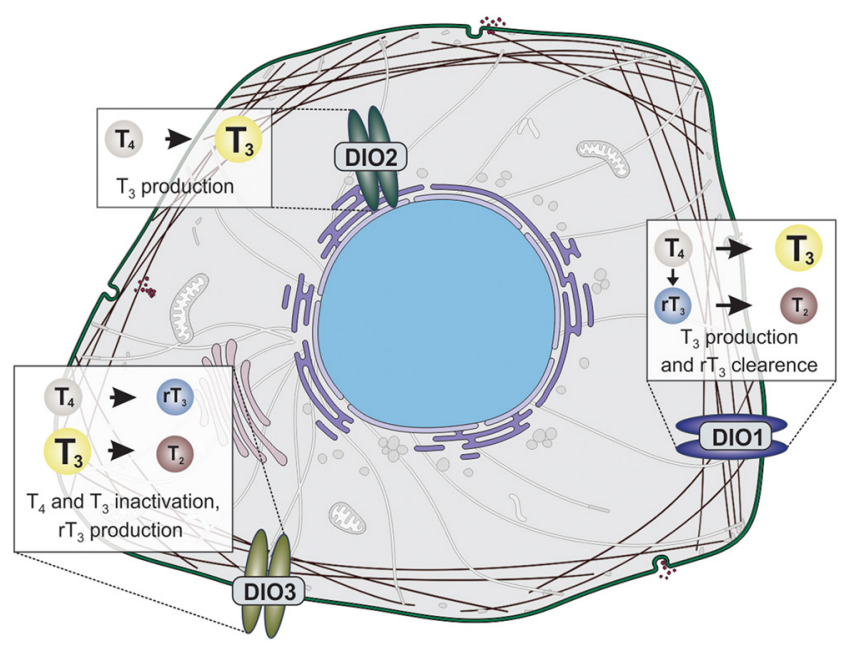

Figure 1

Schematic representation of the localization of deiodinases within the cell as well as the main steps of deiodination by which iodothyronines are generated. DIO1 and DIO3 are located in the plasma membrane, while DIO2 is located in the endoplasmatic reticulum. DIO1 catalyzes both ORD and IRD, promoting both $\mathrm{TH}$ activation (generating $\mathrm{T}_{3}$ from $\mathrm{T}_{4}$ ) and inactivation (generating $\mathrm{rT}_{3}$ from $\mathrm{T}_{4}$ ). DIO2 is responsible for exclusive ORD, yielding $T_{3}$ from $T_{4}$. DIO3 is an exclusive TH inactivating enzyme, generating $T_{2}$ from $T_{3}$ and $\mathrm{rT}_{3}$ from $\mathrm{T}_{4}$. Cell graphic representation adapted from the Human Protein Atlas (https://www.proteinatlas.org/ images_static/cell.svg).

6-propyl-2-thiouracil (PTU) inhibition (Visser et al. 1975, Leonard \& Rosenberg 1978, Ishii et al. 1981). However, PTU did not inhibit the local deiodination of $\mathrm{T}_{4}$ to $\mathrm{T}_{3}$ in brain and pituitary tissues, suggesting the existence of two separate pathways of enzymatic ORD in these tissues. Investigation of the distinct biochemical properties of a possible second enzyme led to the identification of type 2 deiodinase (DIO2, DIO2) (Visser et al. 1981). DIO2 has a $K_{\mathrm{m}}$ for $\mathrm{T}_{4}$ that is approximately three orders of magnitude lower than that of DIO1 in in vitro conditions. The observations that higher rates of IRD occur in neonatal tissues and that high levels of $\mathrm{rT}_{3}$ are present in fetal serum, led to the identification of a specific enzyme responsible for IRD, generating $\mathrm{rT}_{3}$ from $\mathrm{T}_{4}$ and 3,3'-diiodothyronine $\left(3,3^{\prime}-\mathrm{T}_{2}\right)$ from $\mathrm{T}_{3}$. This enzyme was subsequently demonstrated to be type 3 deiodinase (DIO3, DIO3) (Fig. 1) (Kaplan et al. 1983, Tanaka et al. 1992). DIO3 has a much lower $K_{\mathrm{m}}$ for $\mathrm{T}_{4}$ than DIO1 and is the main enzyme involved in $\mathrm{TH}$ inactivation. This enzyme controls $\mathrm{TH}$ homeostasis locally, protecting the tissues, such as the brain and fetal tissues, from an excess of THs (Ciavardelli et al. 2014).

Deiodinases are selenoproteins, meaning they contain a single selenocysteine residue (SeC) in the catalytic center, which is highly conserved between the three enzymes. To incorporate the SeC into the amino acid chain, the cell must recognize the UGA as a Sec codon rather than a
STOP translation signal. This is performed by a stem-loop structure in the 3' untranslated region (UTR) called the Sec insertion sequence (SECIS) element. The SECIS element is the signal that recodes the UGA from a STOP to a Sec codon (Berry et al. 1991a,b). The three enzymes depend on a yet unidentified physiologic thiol cofactor that is substituted during in vitro reactions by reduced dithiols such as dithiothreitol (DTT). The group of selenoproteins still intrigues us due to their peculiar characteristics and mechanisms of action (Schweizer \& Steegborn 2015). The mechanism of reductive deiodination of iodothyronines is not yet fully understood. Recently, the crystal structure of the type 3 deiodinase catalytic domain was identified, and it was shown to resemble the family of peroxiredoxin(s) (Prx). These findings can explain some previously enigmatic features of deiodinase biochemistry and confirms its thioredoxin (Trx) scaffold, suggesting that dimerization is mediated by the catalytic domain and primarily by the N-terminal region of the protein. Moreover, dimerization activates the enzyme by relaxing an autoinhibitory loop, providing access to the binding site. Analysis of Dio3 structure further reveals deiodinase-specific features classifying them as evolutionarily related to atypical 2-Cys Prx. Structure and biochemical data suggest that oxidized enzyme can be directly reduced by exogenous thiols in vitro. These data suggest an evolutionary pathway with Prx as an ancestor of iodothyronine deiodinase (Schweizer et al. 2014).

Deiodinases are Trx fold-containing dimeric enzymes with a molecular weight that varies between 29 and $33 \mathrm{kDa}$ (each monomer) that are located in the plasma membrane (DIO1 and DIO3) and in the endoplasmatic reticulum (ER) (DIO2) (Gereben et al. 2008). All three deiodinase enzymes are integral membrane proteins and are subject to dimerization (Curcio-Morelli et al. 2003a). While DIO1 and DIO3 expression are known to be controlled mainly through pretranscriptional mechanisms, DIO2 is uniquely known for its post-transcriptional activityinduced inactivation. The inactivation process involves ubiquitination of the active enzyme by WD repeat and SOCS box-containing protein 1 (WSB-1), which leads to an inactive DIO2 conformation, followed by proteasomal degradation (Steinsapir et al. 2000, Dentice et al. 2005, Sagar et al. 2007). However, DIO2 can also be reactivated through deubiquitination by ubiquitin-specific peptidase 33 (USP33) (Curcio-Morelli et al. 2003b). DIO1 activity is also regulated by rT3 in a post-translational level through a mechanism that possibly involves post-catalytic structural changes in the DIO1 homodimer inactivating the enzyme (Zhu et al. 2012). The mechanism of substrate- http://erc.endocrinology-journals.org https://doi.org/10.1530/ERC-18-0097 (c) 2019 Society for Endocrinology Published by Bioscientifica Ltd. Printed in Great Britain 
induced inactivation of DIO2 and DIO1 suggests that this regulation might be applicable to all three deiodinases (Schweizer \& Steegborn 2015). There is also evidence of post-transcriptional regulation of DIO3. Drug-induced hepatotoxicity decreased DIO3 protein levels in rat liver, although DIO3 mRNA levels were not changed (Dudek et al. 2013). Moreover, whole-cell deiodination assays with peroxiredoxin 3 (Prx3) knockdown strongly indicate that this DIO3-associated protein plays a specific role in DIO3 regeneration, contributing to the posttranslational regulation of the enzyme (Aerts et al. 2009).

In humans, DIO1 is mainly expressed in the liver, the kidney and the thyroid gland (Maia et al. 2011). DIO2 expression, however, is more widely distributed. DIO2 mRNA and/or DIO2 activity are found in the human thyroid, esophagus, heart, brain, pituitary, skeletal muscle, skin, brown adipose tissue and reproductive organs (Fig. 2) (Kaplan et al. 1988, Croteau et al. 1996, Salvatore et al. 1996a,b, de Jesus et al. 2001, Gouveia et al. 2005).

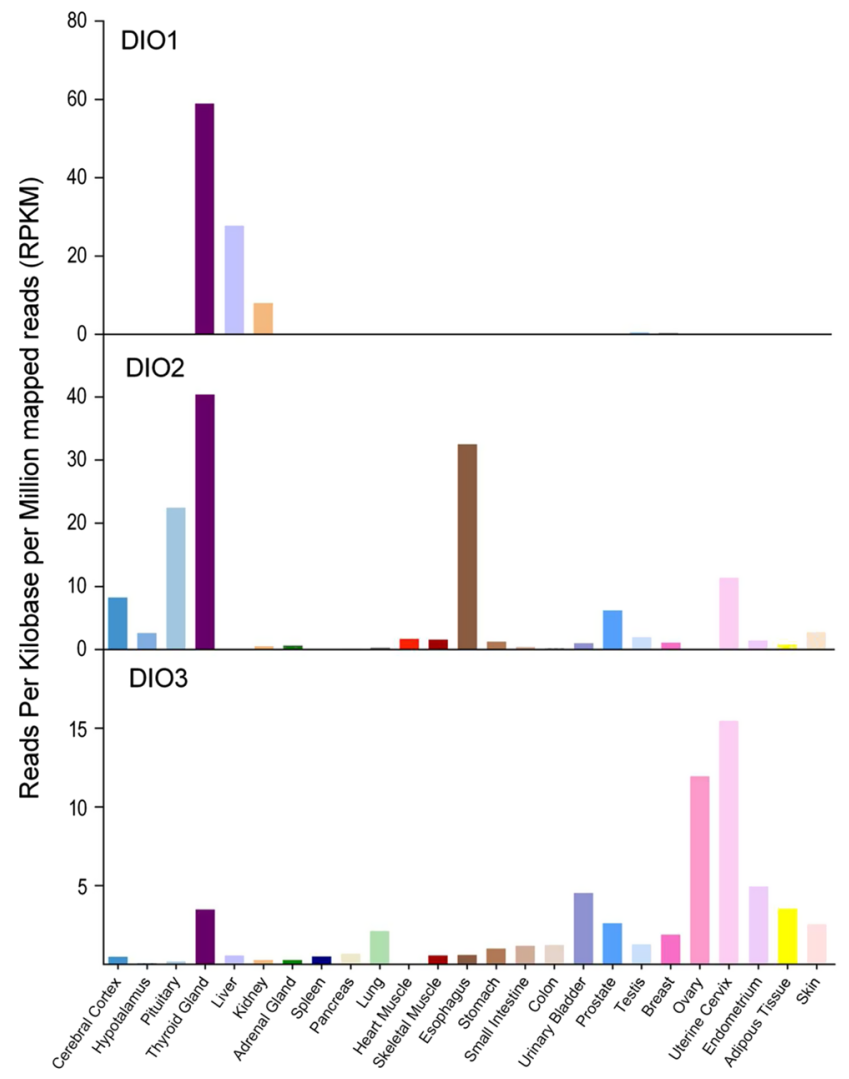

Figure 2

Graphic representation of mean mRNA levels of DIO1, DIO2 and DIO3 in human tissues. RNA-Seq data are reported as the median reads per kilobase per million mapped reads (RPKM) generated by the GenotypeTissue Expression (GTEx) project (Consortium GT 2013). Data were downloaded from the Human Protein Atlas available at v18. proteinatlas. org (www.proteinatlas.org) (Uhlen et al. 2015).
The administration of PTU (which inhibits DIO1 activity) to hypothyroid individuals receiving levothyroxine supplementation reduces $\mathrm{T}_{3}$ production by only approximately 25\% (Saberi et al. 1975), supporting in vitro studies that show that PTU-insensitive deiodination by DIO2 is a major source of $\mathrm{T}_{3}$ in humans (Maia et al. 2005). DIO2 plays an essential role in different organs and systems regulating local $\mathrm{T}_{3}$ production. In a system that transiently coexpresses DIO1 and DIO2, analysis of deiodination at physiologic free $\mathrm{T}_{4}$ levels demonstrates that DIO2 has a much higher catalytic efficiency than DIO1 and is the primary source of extrathyroid-produced $\mathrm{T}_{3}$ in the euthyroid state (Maia et al. 2005). DIO3, which is translated from a paternally imprinted gene and is located in the DLK-DIO3 genomic region, is significantly increased in several tissues during embryogenesis, such as the embryonic liver, cerebral cortex, gonads, intestine and skin. It is critical for TH homeostasis in this context, as exposure of the embryo to high TH levels can be detrimental to proper development (Visser \& Schoenmakers 1992, Ciavardelli et al. 2014). It is also expressed in the placenta, where it broadly protects the fetus from excessive $\mathrm{TH}$ exposure (Salvatore et al. 1995, Koopdonk-Kool et al. 1996, Huang et al. 2003). Importantly, DIO3 is reexpressed in normal and pathological hyperproliferative conditions. DIO3 reactivation has been demonstrated in the pathological context of cardiac hypertrophy, myocardial infarction, critical illness and several types of cancer (Huang 2005, Wajner et al. 2011, Lehnen et al. 2017).

Several signaling pathways and hormonal stimuli regulate deiodinase expression and activity in normal tissue. The human DIO1 gene is under the control of GC-rich SP1 promoters and contains two thyroid hormone response elements that contribute to the $T_{3}$ responsiveness of the DIO1 promoter (Toyoda et al. 1995, Jakobs et al. 1997, Zhang et al. 1998). The most potent modulator of DIO1 activity is $\mathrm{T}_{3} . \mathrm{T}_{3}$ promotes transcriptional activation of the dio1 gene in the rat and the mouse in a process that does not require protein synthesis (Berry et al. 1990, Maia et al. 1995a,b). Although studies of developmental changes with embryonic chickens showed a causal relationship between the increase in plasma growth hormone $(\mathrm{GH})$ and $\mathrm{T}_{3}$ levels, no changes in DIO1 mRNA were observed (Darras et al. 1992, Van der Geyten et al. 1999). However, GH (and also dexamethasone) decreased DIO3 activity by acting at the pre-translational level, which could explain the increased levels of $\mathrm{T}_{3}$ in this model (Van der Geyten et al. 1999). DIO1 is also positively regulated by the adenylyl cyclase (cAMP) cascade, hepatocyte nuclear factor 4 alpha (HNF4A), 
liver $\mathrm{X}$ receptor alpha, thyroid-stimulating hormone (TSH), prolactin and beta-adrenergic stimulation (Ishii et al. 1983, Aceves et al. 1995, Beech et al. 1995, Ohguchi et al. 2008). Forkhead box (FOX) transcription factors play a key role in the regulation of crucial biological processes, including cell proliferation and metabolism (Lam \& Gomes 2014). Interestingly, forkhead box A1 (FOXA1) and forkhead box A2 (FOXA2) regulate DIO1 expression in liver. DIO1 is positively regulated by FOXA1 and negatively regulated by FOXA2 (Kanamoto et al. 2012). DIO1 has been shown to be negatively regulated by cytokines, such as interleukin-1 beta and tumor necrosis factor alpha. However, stimulatory or inhibitory effects of these molecules depend on the type of cytokine, the species and the organ studied (Ongphiphadhanakul et al. 1994, Davies et al. 1997, Baur et al. 2000, Jakobs et al. 2002, Boelen et al. 2004).

DIO2 mRNA and DIO2 activity levels are upregulated by epidermal growth factor (EGF), cAMP, nuclear factor kappa B, forkhead box O3, peroxisome proliferatoractivated receptor gamma, forskolin, bile acids and betaadrenergic agonists (Song \& Oka 2003, Fekete et al. 2004, Grozovsky et al. 2009, Dentice et al. 2010, Bianco 2011). In contrast, DIO2 is negatively regulated at both the pretranslational and post-translational level by THs and at the pre-translational level by tumor necrosis factor alpha, dexamethasone, forkhead box protein $\mathrm{O} 1$ and liver $\mathrm{X}$ receptor/retinoid X-receptor pathway (Bianco et al. 1992, Burmeister et al. 1997, Tu et al. 1997, Hosoi et al. 1999, Song \& Oka 2003, Christoffolete et al. 2010, Lartey et al. 2015). Platelet-derived growth factor and basic fibroblast growth factor (bFGF), which are essential mitogens for vascular smooth muscle cells, cause the induction of DIO2, which is mediated at least partially by the extracellular signal-regulated kinases (ERK) $1 / 2$ pathway (Maeda et al. 2003). GATA2, a transcription factor that determines thyrotroph differentiation, also stimulates DIO2 promoter, as do GATA4 and Homeobox protein Nkx-2.5, central regulators of tissue-specific transcription in cardiomyocytes (Dentice et al. 2003, Matsunaga et al. 2015).

The hedgehog signaling pathway transmits the required information to embryonic cells for appropriate cell differentiation and is considered to be one of the critical regulators of vertebrate development (Ingham \& McMahon 2001). Among the hedgehog homolog proteins, Sonic hedgehog ( $\mathrm{Shh}$ ) is the most studied and is involved in the development of the brain, skeleton, musculature, gastrointestinal tract and lungs (Villavicencio et al. 2000). The Shh pathway has also been implied in neoplastic processes (Taipale \& Beachy 2001) and importantly modulates both DIO2 and DIO3 expression. DIO2 is downregulated post-transcriptionally primarily by ubiquitination (Dentice et al. 2005) while DIO3 is subjected to Shh upregulation through the transcription regulator zinc finger protein GLI2 (GLI2) in normal keratinocytes (Dentice et al. 2007). $T_{3}$, retinoic acid, 12-O-tetradecanoyl-phorbol-13-acetate (TPA) and bFGF induce DIO3 expression and DIO3 activity in rat astrocytes. The effects of TPA and bFGF seem to be mediated by the mitogen-activated protein kinase (MAPK) signaling pathway (Pallud et al. 1999). The DIO3 gene is also transcriptionally induced by transforming growth factor beta (TGFB) via a Smad and MAPK-dependent pathway, by hypoxia-inducible factor 1 alpha (HIF1A) and by Wnt/beta-catenin pathway (Huang et al. 2005, Simonides et al. 2008, Dentice et al. 2012, Romitti et al. 2016).

\section{Thyroid hormone levels and the neoplastic process}

Depletion of THs or their excess promotes modifications in tumoral growth and development. These changes correspond to the ability of THs to promote or inhibit cell proliferation in a cell type-dependent manner, as well as to induce differentiation, in a process linked to growth arrest and exit from the cell cycle. Indeed, THs seem to exert their effects in all hallmarks of the neoplastic process, which include sustained proliferation signaling, resistance to growth suppressors, evasion of programmed cell death, replicative immortality, sustained angiogenesis and promotion of invasion and metastasis (Goemann et al. 2017).

In plasma, the amount of total $\mathrm{T}_{4}$ exceeds the amount of $\mathrm{T}_{3}$ by two orders of magnitude (Bianco \& Kim 2006). Both $\mathrm{T}_{4}$ and $\mathrm{T}_{3}$ enter the cell via transporters, including the monocarboxylate transporter 8 (MCT8) and the organic anion transporting polypeptide C1 (Jansen et al. 2005, Friesema et al. 2006). $T_{4}$ can be deiodinated to $T_{3}$ in the intracellular environment by DIO2. In contrast, DIO3 acts locally to decrease cellular $\mathrm{T}_{3}$ concentrations. Thereby, the deiodinases are critical for the regulation of intracellular $\mathrm{T}_{3}$ levels and therefore contribute to hormone nuclear concentration and saturation of thyroid hormone receptors (TRs) (Wu \& Koenig 2000).

It is widely accepted that $\mathrm{T}_{4}$, which comprises the main secretory product of the thyroid gland is a prohormone and must be converted to the active form $\mathrm{T}_{3}$ by DIO1 or DIO2 to promote $\mathrm{TH}$ metabolic 
effects. However, increasing evidence suggests that $\mathrm{T}_{4}$ can promote nongenomic effects through direct interactions with several pathways, particularly in the context of neoplasia. This broad issue has been recently reviewed by our group and others and will not be discussed here (Davis et al. 2016, Goemann et al. 2017). It should also be noted that $\mathrm{rT}_{3}$, which is generally regarded as an inactive metabolite, seems to be relevant to the structure of both normal cells and tumor cells, by supporting the integrity of the actin cytoskeleton (Farwell et al. 2005). Critical intracellular signaling pathways, such as MAPK, Wnt and Shh are dysregulated in tumoral cells, which may lead to upregulation or downregulation of the deiodinase enzymes depending on the context. Moreover, the theory of the stem cell origin of neoplastic cells, and the relevant role of DIO3 in stemness, suggests an essential role of DIO3 in tumor development (Ciavardelli et al. 2014). The yet unidentified reducing cofactor of deiodinases might be subject to alterations in redox and oxidative stress, which are well-known characteristics of the neoplastic microenvironment (Koppenol et al. 2011). Thus, the catalytic efficiency of deiodinases can be impaired by neoplastic conditions (Wajner et al. 2011).

Changes in deiodinase expression have been reported in several neoplasias (Table 1) (Meyer et al. 2007, Piekielko-Witkowska \& Nauman 2011, Casula \& Bianco 2012, Dentice et al. 2013). One of the best examples of how changes in deiodinases might alter $\mathrm{TH}$ concentrations is the clinical condition of consumptive hypothyroidism, a severe form of hypothyroidism due to high levels of DIO3 activity in the neoplastic tissues. It was first described in infantile liver hemangiomas (Huang et al. 2000). Subsequently, pediatric and adult liver vascular tumors were also associated with increased expression and activity of DIO3 (Huang et al. 2002, Weber Pasa et al. 2017). Indeed, large vascular tumors can express enough DIO3 sufficient to inactivate a significant amount of plasma $\mathrm{T}_{3}$ and cause overt hypothyroidism. DIO3 upregulation occurs through the Shh pathway and the MAPK signaling cascade in these types of tumors (Aw et al. 2014). However, infantile hemangiomas origin is not fully elucidated. Current evidence suggests that hemangiomas are clonal proliferation of fetal endothelial cells, not hepatocytes. Another hypothesis speculates that these cells are derived from the placenta (Boye et al. 2001, Chen et al. 2013). Interestingly, either type of cells express a significant amount of DIO3 protein (Huang et al. 2003), what corroborates the suggestion that these tumors arise from other cells than hepatocytes.
As deiodinases control TH levels, they also contribute to the balance between proliferation and differentiation within the cell. Few studies have actually evaluated both deiodinase expression and intracellular TH concentrations at the same time (see the data below regarding basal cell carcinoma, glioblastoma and clear cell renal cell carcinoma) (Table 1) (Nauman et al. 2004, Dentice et al. 2007, Master et al. 2010). Nevertheless, it is important to keep in mind that disturbed deiodinase expression can go beyond the regulation of intracellular levels of $\mathrm{T}_{4}$ and $\mathrm{T}_{3}$ in the tumoral context. The upregulation or downregulation of deiodinases can reflect the overactivation or suppression of critical signaling pathways involved in carcinogenesis. Moreover, the expression of deiodinases may be a marker of hypermethylation or hypomethylation of the DNA regions where they are located, indicating that they may just represent a small portion of a bigger picture of aberrant cell function. Indeed, several tumor-related aberrations in the chromosomal regions of DIO1, DIO2 and DIO3 have been described (Piekielko-Witkowska \& Nauman 2011). Thus, since the neoplastic process has distinct tissue-related features, it is reasonable to speculate that examining the role of deiodinases in specific tumoral contexts can render a better understanding whether they are a cause or a consequence of neoplastic cellular imbalance.

\section{The thyroid: a classical model}

Significant amounts of ORD are found in normal thyroid tissue due to the high expression of DIO1 and DIO2 (Ishii et al. 1981, Ishii et al. 1982, Sugawara et al. 1984, Salvatore et al. 1996b). DIO1 is the main enzyme responsible for $\mathrm{T}_{3}$ production within the gland. DIO3 activity is regarded as being absent in the thyroid, but traces of DIO3 mRNA transcripts have been found in human thyroid tissue samples (Romitti et al. 2012, Uhlen et al. 2015) (Fig. 2). When evaluating thyroid nodules, an increased 5' deiodination was observed in toxic and also follicular adenomas, while decreased activity was found in cold nodules when compared to healthy tissue (Sugawara et al. 1984, Brtko et al. 2002).

Differentiated thyroid cancer from follicular cells is the most common malignant neoplasia of the endocrine system. Papillary thyroid carcinoma (PTC) is the most prevalent histologic type accounting for more than $90 \%$ of cases, while follicular thyroid carcinoma (FTC) is responsible for the remaining cases (https://seer.cancer. gov/statfacts/html/thyro.html, Accessed on 02/09/2018) (Haugen et al. 2016). Genetic activation of the MAPK 
Table 1 Expression of deiodinases in different types of cancer in humans.

\begin{tabular}{|c|c|c|c|c|c|c|}
\hline Tumor & DIO1 & DIO2 & DIO3 & $\begin{array}{l}\text { Overall effect on } \\
\text { intracellular } T_{3} \\
\text { levels }\end{array}$ & $\begin{array}{l}\text { Potential effect of } \\
T_{3} \text { on hallmarks of } \\
\text { cancer }\end{array}$ & References \\
\hline $\begin{array}{l}\text { Basal cell } \\
\text { carcinoma }\end{array}$ & $\mathrm{N} / \mathrm{A}$ & $\begin{array}{l}\text { Increased } \mathrm{DIO} \\
\text { mRNA levels, } \\
\text { presence of DIO2 } \\
\text { activity levels }\end{array}$ & $\begin{array}{l}\text { Increased } \mathrm{DIO} 3 \\
\text { mRNA, protein } \\
\text { and enzymatic } \\
\text { activity levels }\end{array}$ & Decreased* & $\begin{array}{l}\text { Promotes } \\
\text { proliferation } \\
\text { and decreases } \\
\text { apoptosis }\end{array}$ & $\begin{array}{l}\text { Dentice et al. } \\
\text { (2007), Miro } \\
\text { et al. (2017) }\end{array}$ \\
\hline Breast cancer & $\begin{array}{l}\text { Increased mRNA } \\
\text { and enzyme } \\
\text { activity levels, } \\
\text { particularly in } \\
\text { the most } \\
\text { differentiated } \\
\text { subtypes }\end{array}$ & $\begin{array}{l}\text { DIO2 mRNA } \\
\text { upregulated in } \\
\text { MDA-MB-231 } \\
\text { cell line but not } \\
\text { in MCF-7 cell line }\end{array}$ & $\begin{array}{l}\text { DIO3 mRNA } \\
\text { upregulation is } \\
\text { found in } \\
\text { MCF-7 cells, } \\
\text { and DIO3 } \\
\text { protein is } \\
\text { present in } \\
\text { breast cancer } \\
\text { samples }\end{array}$ & $\begin{array}{l}\text { Changes in } \\
\text { deiodinases } \\
\text { status involve } \\
\mathrm{T}_{3} \text { activation } \\
\text { and } \\
\text { inactivation } \\
\text { and its } \\
\text { 'consequences' } \\
\text { on intracellular } \\
\text { TH } \\
\text { concentrations } \\
\text { are unclear }\end{array}$ & $\begin{array}{l}\text { Influences cell } \\
\text { proliferation }\end{array}$ & $\begin{array}{l}\text { Garcia-Solis and } \\
\text { Aceves (2003), } \\
\text { Debski et al. } \\
\text { (2007), Rusolo } \\
\text { et al. (2017), } \\
\text { I M Goemann, } \\
\text { V Marczk, } \\
\text { A L Maia } \\
\text { (unpublished } \\
\text { observations) }\end{array}$ \\
\hline $\begin{array}{l}\text { Clear cell renal } \\
\text { carcinoma }\end{array}$ & $\begin{array}{l}\text { Decreased mRNA } \\
\text { and enzyme } \\
\text { activity levels }\end{array}$ & N/A & N/A & $\begin{array}{l}\text { Decreased } \\
\text { (measured) }\end{array}$ & $\begin{array}{l}\text { Stimulates } \\
\text { proliferation } \\
\text { and invasion, } \\
\text { contributes to } \\
\text { oxidative stress } \\
\text { response }\end{array}$ & $\begin{array}{l}\text { Pachucki et al. } \\
\text { (2001), } \\
\text { Poplawski \& } \\
\text { Nauman } \\
\text { (2008), } \\
\text { Poplawski } \\
\text { et al. }(2017 a, b)\end{array}$ \\
\hline $\begin{array}{l}\text { Colorectal } \\
\text { cancer }\end{array}$ & $\mathrm{N} / \mathrm{A}$ & $\mathrm{N} / \mathrm{A}$ & $\begin{array}{l}\text { Upregulation of } \\
\text { DIO3 mRNA, } \\
\text { higher protein } \\
\text { expression in } \\
\text { cancer samples } \\
\text { when } \\
\text { compared to } \\
\text { normal tissue }\end{array}$ & Decreased* & $\begin{array}{l}\text { Induces } \\
\text { proliferation }\end{array}$ & $\begin{array}{l}\text { Dentice et al. } \\
\text { (2012) }\end{array}$ \\
\hline Glioma & N/A & $\begin{array}{l}\text { Increased } \mathrm{DIO} 2 \\
\text { mRNA and DIO2 } \\
\text { activity levels }\end{array}$ & $\begin{array}{l}\text { Variable levels } \\
\text { of DIO3 mRNA } \\
\text { and DIO3 } \\
\text { activity }\end{array}$ & $\begin{array}{l}\text { Decreased } \\
\text { (measured) }\end{array}$ & $\begin{array}{l}\text { Induces } \\
\text { proliferation }\end{array}$ & $\begin{array}{l}\text { Mori et al. } \\
\text { (1993), } \\
\text { Murakami } \\
\text { et al. (2000), } \\
\text { Nauman et al. } \\
\text { (2004) }\end{array}$ \\
\hline Hemangioma & $\begin{array}{c}\text { Decreased DIO1 } \\
\text { activity levels }\end{array}$ & $\mathrm{N} / \mathrm{A}$ & $\begin{array}{l}\text { Increased DIO3 } \\
\text { mRNA and } \\
\text { DIO3 activity }\end{array}$ & $\begin{array}{l}\text { Decreased } \\
\text { (measured) }\end{array}$ & $?$ & $\begin{array}{l}\text { Huang et al. } \\
\text { (2000), } \\
\text { Kornasiewicz } \\
\text { et al. (2010), } \\
\text { Kornasiewicz } \\
\text { et al. (2014) }\end{array}$ \\
\hline Lung cancer & $\begin{array}{c}\text { Decreased DIO1 } \\
\text { activity levels }\end{array}$ & $\begin{array}{l}\text { DIO2 activity } \\
\text { similar to normal } \\
\text { lung tissue }\end{array}$ & $\begin{array}{c}\text { Decreased DIO3 } \\
\text { mRNA levels }\end{array}$ & $\begin{array}{l}\text { Changes in } \\
\text { deiodinases } \\
\text { status involve } \\
\mathrm{T}_{3} \text { activation } \\
\text { and } \\
\text { inactivation } \\
\text { and its } \\
\text { 'consequences' } \\
\text { on intracellular } \\
\text { TH } \\
\text { concentrations } \\
\text { are unclear }\end{array}$ & $?$ & $\begin{array}{l}\text { Wawrzynska } \\
\text { et al. (2003), } \\
\text { Molina-Pinelo } \\
\text { et al. (2018) }\end{array}$ \\
\hline
\end{tabular}

(Continued) http://erc.endocrinology-journals.org https://doi.org/10.1530/ERC-18-0097
(C) 2019 Society for Endocrinology Published by Bioscientifica Ltd. Printed in Great Britain 
Table 1 Continued.

\begin{tabular}{|c|c|c|c|c|}
\hline Tumor & DI01 & DIO2 & DIO3 & $\begin{array}{l}\text { Overall effect on } \\
\text { intracellular } T_{3} \\
\text { levels }\end{array}$ \\
\hline $\begin{array}{l}\text { Papillary thyroid } \\
\text { cancer }\end{array}$ & $\begin{array}{l}\text { Decreased DIO1 } \\
\text { mRNA and } \\
\text { DIO1 activity } \\
\text { levels }\end{array}$ & $\begin{array}{l}\text { Decreased } \mathrm{DIO2} \\
\text { mRNA and DIO2 } \\
\text { activity levels }\end{array}$ & $\begin{array}{l}\text { Increased DIO3 } \\
\text { mRNA and } \\
\text { DIO3 activity } \\
\text { levels }\end{array}$ & Decreased* \\
\hline
\end{tabular}

\begin{tabular}{l}
$\begin{array}{l}\text { Potential effect of } \\
\mathbf{T}_{\mathbf{3}} \text { on hallmarks of } \\
\text { cancer }\end{array}$ \\
\hline Induces \\
proliferation \\
and invasion
\end{tabular}

References

Toyoda et al. (1992), Köhrle et al. (1993), Murakami et al. (2001), Ambroziak et al. (2005), de Souza Meyer et al. (2005), Romitti et al. (2012)

Pituitary tumors Both $\mathrm{DIO} 1$ and $\mathrm{DIO} 2$ activities are detected in tumoral and normal tissues in variable levels

$\begin{array}{cl}\text { Increased DIO3 } & \begin{array}{c}\text { Changes in } \\ \text { mRNA, }\end{array} \\ \text { deiodinases } \\ \text { variable DIO3 } & \text { status involve } \\ \text { activity levels } & \mathrm{T}_{3} \text { activation } \\ & \text { and } \\ & \text { inactivation } \\ & \text { and its } \\ & \text { 'consequences' } \\ & \text { on intracellular } \\ & \text { TH } \\ & \text { concentrations } \\ & \text { are unclear }\end{array}$

Baur et al.

(2002),

Tannahill et al. (2002)
?

Tannah
(2002)

*Intracellular $\mathrm{T}_{3}$ levels were evaluated indirectly by intracellular $\mathrm{T}_{3}$-responsive reporters or inferred according to changes in deiodinases expression. DIO1, deiodinase type 1; DIO2, deiodinase type 2; DIO3, deiodinase type 3; N/A: not available.

signaling pathway is a hallmark of PTC (Cancer Genome Atlas Research Network 2014). DIO1 and DIO2 seem to be underexpressed in PTC (Toyoda et al. 1992, Huang et al. 2001, Murakami et al. 2001, Ambroziak et al. 2005, Romitti et al. 2012). Earlier studies performed in human PTC samples have shown that DIO1 mRNA levels were reduced in all the samples that were analyzed $(n=14)$ when compared to the normal surrounding tissue. This was paralleled by a decrease in DIO1 activity with only one exception of a follicular variant of PTC (de Souza Meyer et al. 2005). Arnaldi et al. also reported significant DIO1 and DIO2 underexpression in most but not all PTC samples that were matched to normal tissue (Arnaldi et al. 2005). On the other hand, increased levels of DIO3 mRNA and DIO3 activity have been demonstrated in human PTC samples. Of interest, PTC tumors carrying the BRAFV600E mutation had the highest levels of DIO3 activity. Moreover, a positive correlation between tumor size and DIO3 activity, as well as an increased DIO3 activity was demonstrated in thyroid tumor samples from patients advanced disease at diagnosis (Romitti et al. 2012).

Taken together, one could speculate that changes in deiodinase expression in PTC could lead to decreased intracellular hormone levels and favor tumor proliferation. The increase in DIO3 and the decrease in DIO1 and possibly DIO2 that lead to diminishing $\mathrm{T}_{3}$ concentrations in the microenvironment could provide an advantage for tumor cell proliferation since THs can block the oncogenic Ras-mediated proliferation that interferes specifically with the activity of the MAPK pathway (Garcia-Silva \& Aranda 2004). Recently, crosstalk between the MAPK and SHH pathways leading to DIO3 upregulation has been demonstrated in human PTC cell lines (Romitti et al. 2012, 2016). In support of this line of reasoning, the inhibition of DIO3 mRNA expression through siRNA decreases cyclin D1 expression and induces a partial G1 phase cell cycle arrest, thereby downregulating cell proliferation (Romitti et al. 2016). These observations indicate that SHH/Gli2 pathway contributes to DIO3 overexpression, suggesting that the consequent decrease in intracellular $\mathrm{T}_{3}$ levels may be a critical factor for tumor proliferation in PTC. MAPK canonical signaling pathway is activated by the BRAFV600E, the most commonly detected BRAF mutation in human PTC. Interestingly, mice expressing the BRAFV600E mutation in thyroid follicular cells developed rapid clinical hypothyroidism (within 48h) (Chakravarty et al. 2011). This might indicate that the reactivation of DIO3 in PTCs that harbor the BRAFV600E mutation through MAPK pathway. However, DIO3 expression was not evaluated in this model. Of note, increased immunostained DIO3 
protein has been observed in FTC but not in medullary or anaplastic thyroid carcinoma samples (Romitti et al. 2012).

In FTC samples, we observed a significant increase in DIO1 mRNA levels compared with nontumoral tissue, while others found comparable levels between the tumoral and the normal tissues or even decreased DIO1 activity (Köhrle et al. 1993, Arnaldi et al. 2005, de Souza Meyer et al. 2005, Takano et al. 2006). DIO1 activity was significantly higher in samples of metastases from follicular carcinoma (de Souza Meyer et al. 2005). Higher DIO2 activity was found in samples of larger metastasis of FTC. However, no significant changes in DIO2 mRNA levels were observed, which suggests that DIO2 upregulation occurs mainly by post-transcriptional regulatory mechanisms (Kim et al. 2003, de Souza Meyer et al. 2005, Takano et al. 2006).

Although DIO2 expression has not been evaluated in normal $\mathrm{C}$ cells, we described detectable DIO2 activity in medullary thyroid cancer (MTC) samples, which was comparable to the amounts in the surrounding normal follicular tissue. DIO2 mRNA and DIO2 activity levels have also been demonstrated in the TT cell line (derived from MTC), which might suggest a potential role of intracellular $\mathrm{T}_{3}$ in this neoplastic tissue (Meyer et al. 2008).

We performed an analysis of The Cancer Genome Atlas (TCGA) database (http://cancergenome.nih.gov/) through Gene Expression Profiling Interactive Analysis (GEPIA) (http://gepia.cancer-pku.cn) (Tang et al. 2017), which is a bioinformatics research platform for the profiling and interactive analysis of cancerous gene expression based on TCGA and Genotype-Tissue Expression (GTEx) public databases (Consortium GT 2013). Intriguingly, analysis of TCGA database showed that DIO1 and DIO3 genes are downregulated in thyroid carcinoma (77\% PTC, 21\% FTC) $(n=512, P<0.01$ for DIO1 and DIO3) compared to matched TCGA and GTEx data of normal tissue. DIO2 expression in tumors is comparable to that in normal tissue (Fig. 3).

\section{Basal cell carcinoma: insights on the imbalance of the proliferation/differentiation equilibrium}

DIO2 and DIO3 mRNA transcripts, as well as DIO2 and DIO3 activities, are present in normal human skin (Kaplan et al. 1988, Santini et al. 2003, Slominski et al. 2002). Basal cell carcinoma (BCC), which is the most common cutaneous malignancy, is a non-melanocytic skin cancer that arises from basal cells (the lower layer of the epidermis) (Sellheyer 2011). Dysregulated hedgehog (Hh) signaling is a hallmark of this neoplasia, due to inactivation of Protein

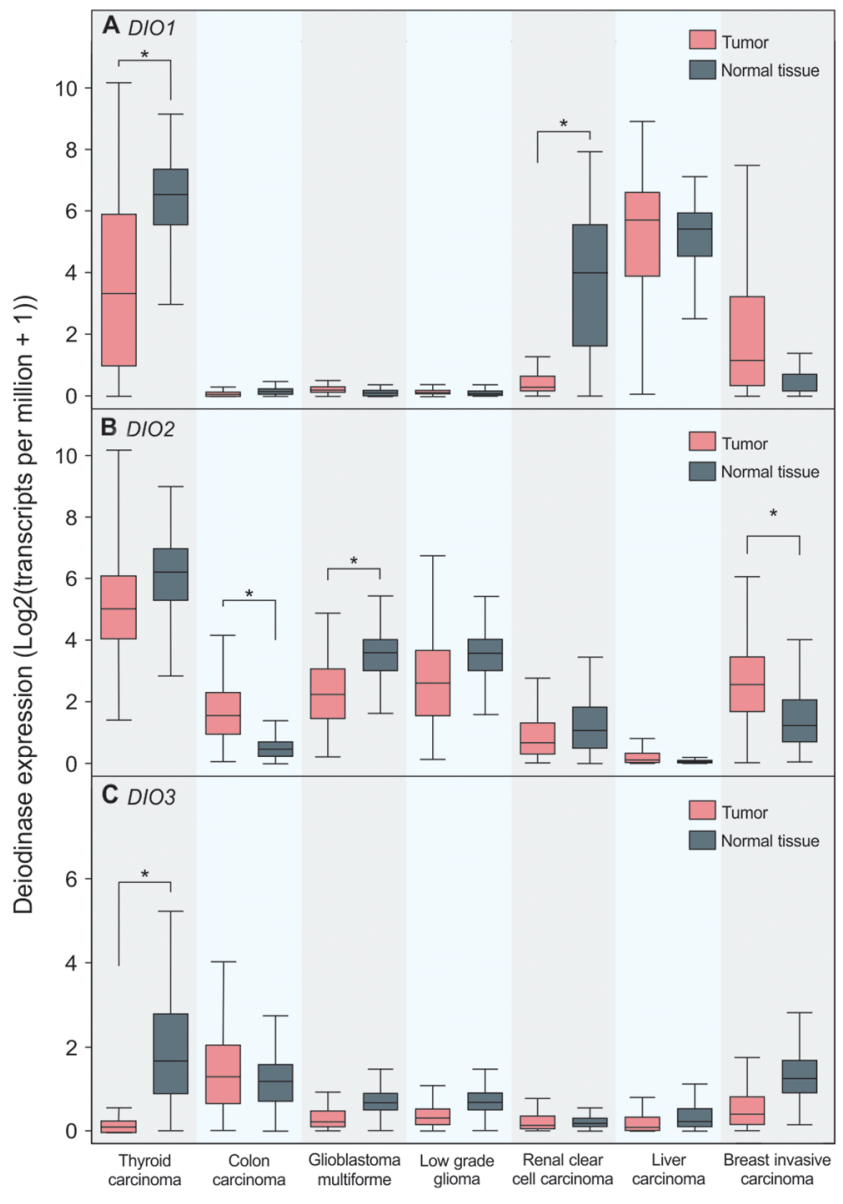

Figure 3

Expression of (A) DIO1, (B) DIO2, and (C) DIO3 in different neoplasias (red) compared to matched TCGA and GTEx data from normal tissue (gray). Expression values are presented in log-scale (log2(transcripts per million (TPM)) + 1). Data were obtained from TCGA and GTEx databases and processed and analyzed with GEPIA. ${ }^{*} P<0.01$.

Patched Homolog 1 (PTCH1), which is an inhibitor of $\mathrm{Hh}$ signaling (Epstein 2008). Most of the research regarding deiodinases and BCC tumorigenesis has been performed by Dentice et al. (Dentice et al. 2007, Luongo et al. 2014, Di Girolamo et al. 2016, Miro et al. 2017). They demonstrated that sonic hedgehog (Shh), through Gli2, directly induces DIO3 in human BCCs, reducing intracellular $\mathrm{T}_{3}$ and thus increasing cyclin D1 and proliferation. Shh also mediates DIO2 reduction through post-transcriptional mechanisms. Thus, DIO3 knockdown blocks proliferation and reduces the oncogenic potential of BCC tumor cells. Indeed, the growth of BCC cells implanted in DIO3-knockdown mice was dramatically reduced, suggesting that $T_{3}$ reduces BCC proliferation and tumorigenic potential (Dentice et al. 2007). Moreover, in G2N2c keratinocyte cells, DIO3 depletion led to the arrest of the cell cycle in $G_{1}$ and to decreases in cyclin D1 levels, further demonstrating that 
cell proliferation is drastically reduced by DIO3 inhibition. Inversely, $\mathrm{T}_{3}$ treatment decreases Gli2 protein levels through upregulation of cAMP/PKA signaling. Whether or not $\mathrm{T}_{3}$ directly affects DIO3 levels in this context is unknown (Luongo et al. 2014). However, $T_{3}$ modulates DIO3 expression indirectly through another pathway. $\mathrm{T}_{3}$ has a suppressive effect on the oncogenic microRNA (miRNA) miR21, which in turn induces DIO3 expression through downregulation of the Grainyhead-like protein 3 homolog (GRHL3). GRHL3 is tumor suppressor factor that is expressed in the skin and is essential for epidermal differentiation. Therefore, the existence of a miR21/GRHL3/DIO3 axis critically contributes to the intracellular $\mathrm{TH}$ imbalance in the context of BCC (Di Girolamo et al. 2016); thus, BCC is an excellent model to study the TH role in the delicate balance between cell proliferation and differentiation. DIO3 mRNA and DIO3 activity have been reported in BCC cells, while only DIO2 mRNA has been demonstrated in these cells. The authors infer the presence of DIO2 activity in BCC cells by the fact that genetically induced depletion of $\mathrm{DIO} 2$ gene using CRISPR/Cas9 technology leads to decreased levels of T3-responsive targets. Therefore artificial modulation of these enzymes can alter the local TH levels, and their effects on tumor growth can be evaluated (Miro et al. 2017). Interestingly, TH activity, as evaluated by a $\mathrm{T}_{3}$-dependent artificial promoter that drives the luciferase gene, is reduced in BCC DIO2KO cells and enhanced in BCC DIO3KO cells. DIO2KO-BCC (low intracellular $\mathrm{T}_{3}$ ) cells are characterized by a high proliferation rate, a high proportion of S-phase cells and decreased apoptosis. On the other hand, DIO3KO-BCC cells have decreased proliferation and low levels of cyclin expression. This interesting model could be expanded to other neoplasias aiming for a better understanding of the effects of THs on cancer (Miro et al. 2017).

\section{Colorectal cancer: deiodinases mediate TH changes as differentiation agents}

Colorectal cancer (CRC) is characterized by a complex array of genetic alterations, among which the mutation in the adenomatous polyposis coli (APC) gene is the most frequent ( $85 \%$ of cases). This mutation leads to a constitutively active Wnt pathway due to inadequate degradation of beta-catenin by the APC protein (Markowitz \& Bertagnolli 2009). Dentice et al. provided the first evidence suggesting an interplay between the Wnt/beta-catenin pathway and the TH signaling pathway in the balance between proliferation and differentiation in colorectal cancer (Dentice et al. 2012). The authors elegantly showed that exogenous $\mathrm{T}_{3}$ treatment reduced proliferation and increased differentiation in vitro in CRCderived cell lines. Moreover, they demonstrated that the activation of Wnt/beta-catenin induced the expression of DIO3 mRNA while decreasing DIO2 mRNA. This dual mechanism could result in intracellular hypothyroidism, favoring proliferation over differentiation. Additionally, they showed that DIO3 depletion had $\mathrm{T}_{3}$-like effects and that xenografts of DIO3-depleted cells exhibited reduced tumor growth.

Dentice and colleagues have also shown DIO3 expression was associated with neoplastic transformation in CRC. Using immunohistochemistry in 105 human paraffin-fixed samples, they observed that DIO3 positivity was found in $10 \%$ of the normal tissues, whereas $80 \%$ of carcinomas and $90 \%$ of adenomas were DIO3 positive, suggesting that DIO3 is a Wnt/beta-catenin target in the context of colon carcinoma proliferation (Dentice et al. 2012). Moreover, $\mathrm{T}_{3}$ treatment or DIO3 inhibition could be used to promote CRC-stem cell (CRC-SC) differentiation via Wnt and BMP4 signaling. Interestingly, TH-induced differentiation increased CRC-SC sensitivity to traditional chemotherapy (oxaliplatin and 5-FU), raising the possibility of combination therapy in the future (Catalano et al. 2016).

The analysis of the public TCGA database through GEPIA demonstrated low expression of DIO1 in CRC and detectable levels of DIO3 mRNA that were similar in tumor tissue and normal tissue (Fig. 3). These findings are in contrast with the findings of Dentice et al. (2012) who found that DIO3 protein levels were increased as evaluated through immunohistochemistry in 22 out of 24 tumors tissue samples compared with normal surrounding tissue. These differences could be attributed to post-translational mechanisms that regulate protein expression as well as to differences in the controls (normal predisposed surrounding tissue vs tissue from healthy individuals). DIO2 was overexpressed in CRC tissue when compared to non-paired tissue $(n=275, P<0.01)$ and was found to be a marker of good prognosis in this database (5-year survival: 66\% in the high expression group vs $46 \%$ in the low expression group; $P<0.01$ ). This is a finding that should be further confirmed.

\section{The glioma model: the adverse effects of $T_{3}$}

Brain cells are uniquely sensitive to the effects of THs; therefore, they require even tighter control of $\mathrm{TH}$ homeostasis when compared to other organs. 
THs stimulate the processes of myelination, the proliferation of glial cells as well as axon growth and formation. The necessity for strict control of $\mathrm{TH}$ levels might explain the detectable activity of DIO2 and DIO3 in glial cells (Visser et al. 1981, Crantz et al. 1982, Silva \& Leonard 1985, Riskind et al. 1987, Ciavardelli et al. 2014). Indeed, studies performed in rat cerebral cortex demonstrate that approximately $80 \%$ of the $\mathrm{T}_{3}$ bound to nuclear receptors is produced locally by monodeiodination of $\mathrm{T}_{4}$ (Crantz \& Larsen 1980, Crantz et al. 1982). DIO3 activity is present in adult human brain tissue, and high DIO3 levels in placental tissue play an essential role in protecting the developing brain of the fetus from excessive $\mathrm{T}_{3}$ concentrations (Campos-Barros et al. 1996, Kester et al. 2004).

Gliomas are tumors arising from the brain parenchyma, with a broad range of aggressiveness. Grades I and II gliomas are referred to as low-grade gliomas, while the more rapidly progressive tumors are referred to as high-grade gliomas (grades III and IV) (Louis et al. 2016). The modulation of intracellular $T_{3}$ and $T_{4}$ levels by deiodinases in glioblastoma is of great importance, since the PI3K, Src kinase and ERK1/2 signaling cascades are parallel pathways that are stimulated by $\mathrm{T}_{3}$ in $\mathrm{U}-87 \mathrm{MG}$ cells, a commonly studied human glioblastoma cell line (Liappas et al. 2011). These are among the most commonly dysregulated pathways in this type of cancer. DIO2 expression and DIO2 activity were found in glioblastoma and were the highest in a tissue sample from an anaplastic oligodendroglioma (Murakami et al. 2000). Nauman et al. made an effort to correlate deiodinase activity and the $\mathrm{T}_{4} / \mathrm{T}_{3}$ concentrations of gliomas and normal surrounding tissue. They found that $\mathrm{T}_{4}$ and $\mathrm{T}_{3}$ concentrations in the tumor tissues were lower than those in the non-tumor tissues in the majority of the patients, whereas DIO2 activity was higher in tumor tissues than in normal tissues (Nauman et al. 2004). In one study, DIO3 activity was detected in samples of gliomas, although no comparison to healthy tissues was performed (Mori et al. 1993). In another study, DIO3 was detected in a heterogeneous manner. In two samples, the DIO3 activity was lower than in the tumor tissue, but in all the high-grade gliomas (IV), the DIO3 activity was considerably higher in the tumoral tissue. These findings suggest that the expression of deiodinases and the metabolism of THs are altered in human brain tumors, and these changes might be related essential factors that contribute to tumorigenesis or tumor growth (Nauman et al. 2004). Finally, it is worth mentioning that limited clinical data suggest that medically induced hypothyroidism may increase patient survival in high-grade glioblastoma (Hercbergs et al. 2003, Ashur-Fabian et al. 2013).

TCGA database analysis through GEPIA demonstrated that DIO2 expression was significantly downregulated in glioblastoma samples $(n=163)$ when compared with non-paired normal tissue. Similarly, DIO3 tended to be underexpressed in glioblastoma tumors when compared to healthy tissue (Fig. 3B and C). However, posttranscriptional factors, as well as substrates and cofactor availability, could explain the discrepancies between these data and the results of previous studies that showed more heterogeneous patterns of enzyme activity. Moreover, TCGA data that were analyzed included only glioblastoma multiforme samples and does not comprise more differentiated tumor subtypes. It is of great importance to evaluate if altered deiodinase expression is modulated by signaling pathways that are often dysregulated in this type of cancer, such as the PI3K, Src kinase and ERK1/2 signaling pathways and to what extent this contributes to tumor aggressiveness.

\section{Clear cell renal carcinoma: TRB1 and DIO1 as tumorigenesis protagonists}

Clear cell renal cell carcinoma (ccRCC) is the most common type of kidney cancer, accounting for approximately $75 \%$ of all cases. One of the first reports of the dysregulation of THs in cancer involved ccRCC, and there have been multiple and consistent reports supporting decreased expression of DIO1 mRNA and DIO1 protein in ccRCC, as well as decreased expression of thyroid hormone receptor beta (THRB)1 (Puzianowska-Kuznicka et al. 2000, Pachucki et al. 2001). Studies indicate that $\mathrm{T}_{3}$ acts through THRB1 as the primary controller of DIO1 expression in the kidney, unlike in other tissues where $T_{3}$ acts through both thyroid hormone receptor alpha and THRB (Amma et al. 2001).

Dysregulation of the splicing mechanisms in ccRCC and the existence of multiple splicing variants of DIO1 mRNA and THRB1 have been consistently reported, suggesting a cause for DIO1 disturbances (PiekielkoWitkowska et al. 2009, Master et al. 2010, PiekielkoWitkowska et al. 2010). Additionally, microRNAs targeting the 3'UTR region of DIO1 mRNA (miR-224 and miRNA383) were reported to be upregulated in ccRCC. The transfection of pre-miRNA-224 or pre-miRNA-383 reduced DIO1 mRNA expression in vitro, confirming the suppressive effect of these miRs in DIO1 expression. Consistent with the downregulation of DIO1, intratumoral $\mathrm{T}_{3}$ levels were $58 \%$ lower than in control tissue (Boguslawska et al. 2011). 
More recently, Poplawski et al. provided clear evidence of DIO1 involvement in tumorigenesis by demonstrating that induction of DIO1 inhibits proliferation and migration and improves adhesion to laminin in ccRCC-derived cell lines (KIJ265T and KIJ308T) (Poplawski et al. 2017a). Moreover, they noted decreased mRNA expression of the genes involved in the G1-to-S transition (cyclin D1, cyclin E2, Cdk2, E2F2) in the KIJ 265T cell line. These findings are in accordance with the previously reported DIO1 downregulation in ccRCC, showing that a lower DIO1 activity could increase proliferation, promote migration and allow cells to detach from ECM proteins more easily. Indeed, DIO1 expression is significantly downregulated in ccRCC when compared to normal samples based on TCGA data analysis through GEPIA $(n=523, P<0.01)$ (Fig. 3A). However, no significant changes in DIO2 and DIO3 expression were found (Fig. 3B and C). Whether these effects are the result of intracellular hypothyroidism due to the insufficient conversion of $T_{4}$ to $T_{3}$ remains unclear. Supplementation of cells with $\mathrm{T}_{3}$ did not reverse the effects of the diminished DIO1 activity. However, this finding might also be due to the inefficient transport of $\mathrm{T}_{3}$ into the cell (Poplawski et al. 2017a). Restoration of DIO1 expression in ccRCC 'downregulates' oncoproteins that promote proliferation, migration, and invasion while triggers proteins involved in regulation of anti-oxidative processes. Together, these results suggest that loss of DIO1 expression could be an adaptive mechanism, protecting the cells against overstimulation of cancer metabolism and induction of apoptosis (Poplawski et al. 2017b).

\section{Liver neoplasias: complex effects of THs, but few data on deiodinase expression}

Classically, significant $\mathrm{T}_{4}$ ORD is found in human liver homogenates (Hardy et al. 1986, Kornasiewicz et al. 2010). When evaluating liver microsomes, high DIO1 and DIO3 activities are detected in fetal liver but only DIO1 and mostly none DIO3 activities are found in adult liver. DIO2 activity is virtually absent in both fetal and adult tissues (Richard et al. 1998). Both human hepatocytes as well as human hepatoblastoma-derived cells HepG2 show an approximately ten-fold lower rate of iodothyronine metabolism when compared to rat hepatocytes (de Jong et al. 1993, van Stralen et al. 1993, 1996). However, deiodinase data in human liver tumors is scarce, and the influence of $\mathrm{TH}$ in hepatocellular carcinoma (HCC) is controversial. While THs seem to reduce growth, they also promote cell migration in hepatoma cell lines (Chen et al. 2008, 2014, Wu et al. 2013) THs can also induce cell self-renewal and promote drug resistance of HCC CSCs (Wang et al. 2016).

In an analysis of 13 benign lesions and 7 samples of hepatocellular carcinoma that were compared to normal tissue, there was no difference in DIO1 activity (Kornasiewicz et al. 2014); however, DIO1 activity was decreased in hepatic hemangiomas (Kornasiewicz et al. 2010). HepG2 express functional DIO1 (van Stralen et al. 1996, Chen et al. 2016) but neither DIO2 or DIO3 activity has been observed in these cells (Kester et al. 2006).

Indirect clinical and basic data also point to a possibility that DIO3 upregulation might occur in HCC. In a case-control trial, the high prevalence of hypothyroidism among patients with HCC (11.7\%) suggested that long-term hypothyroidism was associated with HCC (Hassan et al. 2009). Studies in mouse HCC models have identified a cluster of microRNAs (miRNA) that are involved in the upregulation of the DLK1-DIO3 genomic imprinted region, where the DIO3 gene is located. More interestingly, overexpression of the DLK1-DIO3 miRNA cluster was positively correlated with HCC stem cell markers and associated with a high level of serum $\alpha$-fetoprotein, which is a conventional biomarker for liver cancer and for reduced survival rates in HCC patients (Luk et al. 2011). No differences in deiodinase expression between tumor tissue and normal tissue were observed in TCGA data (Fig. 3).

\section{Breast cancer: deiodinases as markers or effectors?}

THs are essential for mammary gland growth and development (Vonderhaar \& Greco 1979). Studies in rats demonstrate that the mammary glands express significant amounts of functional DIO1 only during the functional stages (lactation) or during differentiation (puberty) (Aceves \& Valverde 1989, Aceves et al. 1995, Navarro et al. 1997). In contrast, DIO2 activity is found in non-stimulated mouse mammary glands, and its expression decreases substantially in the lactating stage (Song et al. 2000). In human non-lactating tissue, low or undetectable DIO1 activity has been demonstrated (Debski et al. 2007) while no difference in DIO1 mRNA expression was observed between normal and lactating tissue (Alyusuf et al. 2014). We were unable to find data on DIO2 and DIO3 expression in human normal breast tissue.

The first studies of TH metabolism in breast cancer were performed in rat mammary adenocarcinoma. The R3230AC mammary adenocarcinoma is an 
estrogen-responsive autonomous tumor that has been maintained by serial transplantation in female Fischer rats since 1963 (Hilf et al. 1967). ORD has been demonstrated in this tumor and is insensitive to PTU, which would be compatible with DIO2 activity, as well as IRD, generating $\mathrm{rT}_{3}$ from $\mathrm{T}_{4}$, suggesting that the deiodination pathways were preserved in this tumor model (Ong et al. 1986). More recently, abundant activity of DIO1 and high DIO1 mRNA levels have been shown in human breast cancer, particularly in the most differentiated subtypes (Debski et al. 2007, Alyusuf et al. 2014). DIO1 activity was also found in the breast cancer cell line MCF-7 (differentiated epithelial carcinoma). However, the more dedifferentiated MDA-MB-231 (estrogen receptor negative) cell line did not express any deiodinase activity (Garcia-Solis \& Aceves 2003). Despite these negative findings, upregulation of DIO1, DIO2 and DIO3 mRNAs has been shown in MCF-7 cells. On the other hand, only DIO2 is upregulated in MDA-MB-231 when these cell lines were compared to non-tumoral human breast cells MCF-10A (Rusolo et al. 2017). The differences between deiodinase mRNA expression and protein activity could be explained by different subtypes of breast tumor as well as posttranscriptional regulatory mechanisms. Taken together, these results may suggest a role for DIO1 as a marker of differentiation in breast neoplasias. It is interesting to correlate these data with the effects of $\mathrm{T}_{3}$ treatment on cell proliferation. $T_{3}$ leads to increased proliferation in MCF-7 cells but does not interfere with the growth of MDA-MB-231 cells (Nogueira \& Brentani 1996, Hall et al. 2008, Cestari et al. 2009).

Analysis of TCGA public data demonstrates that DIO2 expression is upregulated in breast cancer when compared to normal tissue $(n=1085, P<0.01)$ (Fig. 3B), and the other deiodinases expression levels in breast cancer are comparable to normal tissue (Fig. 3A and C). As THs influence the proliferation of breast cancer cells, it is worthwhile to consider that DIO3 expression in mammary neoplasias may play a role in modulating intracellular $\mathrm{T}_{3}$ levels and thus contribute to tumor progression (De Sibio et al. 2014). We observed moderate immunostaining of DIO3 in normal human mammary gland tissue and a significant expression of DIO3 staining in samples of invasive ductal carcinoma (I M Goemann, V Marczk, A L Maia, unpublished observations). DIO3 has also been shown to be expressed in the MCF-7 cell line (Kester et al. 2006, Maynard et al. 2014). To what extent these alterations contribute to tumor growth due to the modulation of intracellular $T_{3}$ or represent markers of altered signaling pathways is yet to be demonstrated.

\section{Deiodinase expression in other neoplasias}

DIO2 expression is induced in most brain tumors derived from glial cells (Mori et al. 1993, Murakami et al. 2000, Nauman et al. 2004). Studies performed in 105 pituitary tumors demonstrated that $\mathrm{DIO} 2$ and $\mathrm{DIO} 3$ mRNA were significantly augmented in pituitary tumors when compared with normal pituitary tissue. However, in the rare TSH-secreting pituitary tumor subtype, the DIO3 mRNA was strongly induced, while reduced DIO2 mRNA levels were detected. Interestingly, in the case of TSHsecreting pituitary adenomas, the observed pattern of deiodinase mRNA expression may explain the 'resistance' of these tumors to TH feedback (Tannahill et al. 2002). When evaluating enzyme function in pituitary adenomas, Baur et al. found both DIO1 and DIO2 activity in normal and tumoral tissue. Of note, highest activities of both enzymes were found in TSH- and PRL-producing adenomas (Baur et al. 2002). These sets of deiodinase abnormalities may have functional consequences on pituitary tumor growth.

The clinical picture of consumptive hypothyroidism is not restricted to liver hemangiomas. A recent systematic review by our group revealed that among children, $97 \%$ had vascular tumors, with hepatic vascular tumors representing $88 \%$ of the cases, parotid hemangiomas $5 \%$, cutaneous hemangiomatosis $2 \%$ and fibrosarcomas $2 \%$. Because there is a high risk of bleeding associated with vascular tumor biopsy, only three patients underwent tissue sampling. High DIO3 activity was confirmed in all tumor specimens. Tumor histology in the adult population differs from that in pediatric patients. Hepatic vascular tumors represented only 33\% of the cases. Gastrointestinal stromal tumors (GISTs) and fibrous tumors each accounted for 33\% of the cases. Functional assays confirmed high DIO3 activity levels in all the adult patients (Maynard et al. 2014, Weber Pasa et al. 2017).

The analysis of deiodination in lung cancer tissue demonstrated that the activity of DIO1 is significantly lower in tumor tissue when compared to the peripheral normal lung tissue, while DIO2 activity is similar in peripheral lung and lung cancer tissue (Wawrzynska et al. 2003). Interestingly, DIO3 was found to be hypermethylated in a subset of hematological malignancies, as assessed by microarray-based methylation analysis, suggesting that aberrant epigenetic modifications may confer DIO3 tumor-associated properties (Martin-Subero et al. 2009). This is also supported by data that demonstrates DIO3 hypermethylation in lung cancer, which was associated with lower levels of DIO3 mRNA expression as compared 
to normal tissue (Molina-Pinelo et al. 2018). Therefore, silencing of DIO3 gene by hypermethylation might be an epigenetic pattern common to different types of human cancer.

\section{Future directions and conclusion}

The set of data summarized here clearly indicates a potential role of alterations in deiodinase-related TH levels on the promotion of human carcinogenesis. In addition to the importance of this evidence, it is critical to keep in mind that these studies mostly show an association between changes in the levels of deiodinases and cancer, demonstrating that there is still a lack of knowledge regarding the direct effect of these enzymes on oncogenic processes. Indeed, the majority of data available so far have been obtained by studies performed in normal and tumor tissues from adult patients, human cancer cell lines and in vivo models of carcinogenesis. By using these models, the most relevant data that specifically analyzed the effect disruption of deiodinases on carcinogenesis were obtained by chemical inhibition or gene knockout/ knockdown. Such approaches may imply the effects of enzyme reactivation on already established tumors and highlight the advantages of such inhibition on tumor behaviors. However, they add limited information to the knowledge of cell transformation and cancer development. Comparative analysis of TCGA and GTEx database can now provide further insight into deiodinases mRNA expression in different types of tumors. Likewise, this approach also has intrinsic limitations. TCGA and GTEx data were not collected in a single experiment. This may especially affect measurements of expression and correlation across different samples. Moreover, GTEx (normal tissue database) RNA are extracted from all tissues of postmortem donors with variable ischemic time (what could compromise RNA quality). On the other hand, TCGA comprises one of the largest and most comprehensive cancer genomics datasets in the world, providing analyses of high-throughput RNA sequencing data of 33 types of cancer, describing tumor tissue and matched normal tissues from more than 11,000 patients. These data are well validated and contributed to more than a thousand studies of cancer by different research groups (https:// cancergenome.nih.gov/). Using the Human Proteome Map project and RNA-Seq measurements from the GTEx project, a comprehensive tissue- and gene-specific analysis of 16,561 genes and the corresponding proteins revealed that across the 14 tissues, the correlation between mRNA and protein expression was positive and ranged from 0.36 to 0.5 (Spearman correlation value) (Kosti et al. 2016). As deiodinases are subject to post-translational regulation as previously described, analysis confined to mRNA expression through public databases should be interpreted carefully, since it may not represent final protein levels and consequent TH changes within the tumor. TCGA also provides additional proteomics data, though only of a limited number of proteins, among which deiodinases are not included (Akbani et al. 2014).

Thus, in vivo and in vitro functional models are needed to fully understand how specific drivers, such as deiodinases, impact tumor initiation and maintenance. Genetically engineered mouse models have been recognized as powerful tools to investigate the impact of gene function on tumorigenesis (Frese \& Tuveson 2007, Dow \& Lowe 2012). Over the last several years, genome engineering and stem cell technologies have allowed the production of strains in which specific genes can be expressed in a tissue-specific manner. With the advent of Cre-lox and CRISPR/Cas9 technologies, conditional knockout and/or knockin alleles can precisely model events associated with human carcinomas. Furthermore, conditional gene expression systems based on the tetracycline (tet) response system or estrogen-receptor (ERT2) fusions allow temporal analysis of gene function. In addition, the insertion of fluorescent reporters enables lineage tracing and examination of activity (Huijbers et al. 2011, Saborowski et al. 2014). These new approaches in combination allowed the generation of genetically and histopathologically accurate in vitro and in vivo models of various human cancers that in turn can be applied to explore the role of the disruption of deiodinases (reactivation and/or downregulation) on cancer initiation and behavior.

In the context of the present review, most of the tumors mentioned above have already been modeled using stem cell technology, which has emerged as a great tool for this kind of research. With regard to the role of genes on the initiation and progression of thyroid cancer, the generation of 3D functional thyroid models derived from mouse embryonic stem cells (mESC) (Antonica et al. 2012) constitutes a major breakthrough in the field of thyroid research and raises opportunities for addressing questions related to thyroid organogenesis and diseases. By the induction of thyroid transcriptional factors (Antonica et al. 2012) or specific pathways with chemical timing in mESCs (Kurmann et al. 2015), these protocols allow us to obtain thyroid cells at different stages of differentiation. In addition, they provide the advantage of generating 3D functional follicles, which is a more sophisticated model 
to address gene effects of thyroid cell transformation and can be easily manipulated using estrogen-receptor fusions, Cre-lox and/or CRISPR/Cas9 technologies (Antonica et al. 2012, 2017)

Human pluripotent stem cells (hPSCs) have been used as a valuable model for studying the development and progression of gliomas. In addition, neural differentiation protocols allow the derivation of relevant early neural stem cells that are often inaccessible. Thus, early tumorigenesis can be studied in the proper cellular context (Chambers et al. 2009, Funato et al. 2014). Gene function tests can be evaluated by mutational models, such as lentiviruses encoding constitutively active forms of mutated genes; and knockdown studies can be performed by using shRNA (Funato et al. 2014). Similarly, human embryonic stem cells (hESCs) and induced pluripotent stem cells (iPSCs) have been used to model human diseases of the large intestine. Through modulation of signaling pathways that are known to regulate normal mouse embryonic development, a stepwise strategy was designed for the progressive generation of definitive endoderm, hindgut endoderm (HE) and subsequently the formation of colonic organoids (COs). These 3D structures constitute the best models that resemble in vivo organ function and are one of the best tools for disease modeling and drug discovery for some types of cancer (Crespo et al. 2017). Therefore, we can make use of this technology to evaluate deiodinase dysregulation and consequent TH imbalance in the fine equilibrium of cellular proliferation and differentiation.

The expression of deiodinases in the neoplastic context is cancer specific and dependent on several clinical and tumoral characteristics. Despite the challenges in studying selenoenzymes in vitro an in vivo, the role of DIO1, DIO2 and DIO3 in each tumoral context is beginning to unravel (Table 1). Deiodinases can function as markers of disease and cell differentiation or play essential roles as intracellular TH regulators, though we still lack data on the potential concomitant function of all enzymes in each neoplastic context. Moreover, deiodinases can participate in signaling pathways through 'TH-independent' mechanisms that need to be further explored. In summary, the understanding of the myriad of mechanisms underlying the balance between tumor cell proliferation and differentiation promoted by THs through deiodinase regulation is critical for the development of new treatment strategies for cancer, inducing tissue-specific or even intracellular changes in TH status that could block excessive proliferation and/or induce tumor redifferentiation.
Declaration of interest

The authors declare that there is no conflict of interest that could be perceived as prejudicing the impartiality of this review.

\section{Funding}

Conselho Nacional de Desenvolvimento Científico e Tecnológico (CNPq) (457547/2013-8); Fundação de Amparo a Pesquisa do Rio Grande do Sul (FAPERGS) (10/0051-9) and Fundo de Incentivo a Pesquisa do Hospital de Clínicas de Porto Alegre (FIPE) (16-0246), Brasil.

\section{References}

Aceves C \& Valverde C 1989 Type I, 5'-monodeiodinase activity in the lactating mammary gland. Endocrinology 124 2818-2820. (https:// doi.org/10.1210/endo-124-6-2818)

Aceves C, Fonte CR, Ramirez CI, Wilson S, Pineda CO, Lopez BL, Mancilla R \& Valverde RC 1995 Mammary 5'deiodinase (5'D) during the breeding cycle of the rat: indirect evidence that $5^{\prime} \mathrm{D}$ type $\mathrm{I}$ is specific to the alveolar epithelium. Endocrine 3 95-99. (https://doi. org/10.1007/BF02990059)

Aerts G, Arrojo EDR, Van Herck SL, Sammels E, Mirebeau-Prunier D, Gereben B, Zeold A, Harney JW, Huang SA, Mulcahey MA, et al. 2009 Knockdown of the type 3 iodothyronine deiodinase (D3) interacting protein peroxiredoxin 3 decreases D3-mediated deiodination in intact cells. Endocrinology 150 5171-5180. (https:// doi.org/10.1210/en.2009-0702)

Akbani R, Ng PK, Werner HM, Shahmoradgoli M, Zhang F, Ju Z, Liu W, Yang JY, Yoshihara K, Li J, et al. 2014 A pan-cancer proteomic perspective on The Cancer Genome Atlas. Nature Communications 5 3887. (https://doi.org/10.1038/ncomms4887)

Alyusuf RH, Matouq JA, Taha S \& Wazir JF 2014 The pattern of expression and role of triiodothyronine (T3) receptors and type I 5 '-deiodinase in breast carcinomas, benign breast diseases, lactational change, and normal breast epithelium. Applied Immunohistochemistry and Molecular Morphology 22 518-523. (https://doi.org/10.1097/ PAI.0b013e3182a20917)

Ambroziak M, Pachucki J, Stachlewska-Nasfeter E, Nauman J \& Nauman A 2005 Disturbed expression of type 1 and type 2 iodothyronine deiodinase as well as titf1/nkx2-1 and pax-8 transcription factor genes in papillary thyroid cancer. Thyroid $\mathbf{1 5}$ 1137-1146. (https://doi.org/10.1089/thy.2005.15.1137)

Amma LL, Campos-Barros A, Wang Z, Vennstrom B \& Forrest D 2001 Distinct tissue-specific roles for thyroid hormone receptors beta and alpha1 in regulation of type 1 deiodinase expression. Molecular Endocrinology 15 467-475. (https://doi.org/10.1210/mend.15.3.0605)

Antonica F, Kasprzyk DF, Opitz R, Iacovino M, Liao XH, Dumitrescu AM, Refetoff S, Peremans K, Manto M, Kyba M, et al. 2012 Generation of functional thyroid from embryonic stem cells. Nature 491 66-71. (https://doi.org/10.1038/nature11525)

Antonica F, Kasprzyk DF, Schiavo AA, Romitti M \& Costagliola S 2017 Generation of functional thyroid tissue using 3D-based culture of embryonic stem cells. Methods in Molecular Biology 1597 85-95. (https://doi.org/10.1007/978-1-4939-6949-4_7)

Arnaldi LA, Borra RC, Maciel RM \& Cerutti JM 2005 Gene expression profiles reveal that DCN, DIO1, and DIO2 are underexpressed in benign and malignant thyroid tumors. Thyroid 15 210-221. (https:// doi.org/10.1089/thy.2005.15.210)

Ashur-Fabian O, Blumenthal DT, Bakon M, Nass D, Davis PJ \& Hercbergs A 2013 Long-term response in high-grade optic glioma treated with medically induced hypothyroidism and carboplatin: a case report and review of the literature. Anticancer Drugs 24 315-323. (https://doi.org/10.1097/CAD.0b013e32835c7a47) 
Aw DK, Sinha RA, Tan HC, Loh LM, Salvatore D \& Yen PM 2014 Studies of molecular mechanisms associated with increased deiodinase 3 expression in a case of consumptive hypothyroidism. Journal of Clinical Endocrinology and Metabolism 99 3965-3971.

Baur A, Bauer K, Jarry H \& Kohrle J 2000 Effects of proinflammatory cytokines on anterior pituitary 5 '-deiodinase type I and type II. Journal of Endocrinology 167 505-515. (https://doi.org/10.1677/ joe.0.1670505)

Baur A, Buchfelder M \& Kohrle J 2002 Expression of 5'-deiodinase enzymes in normal pituitaries and in various human pituitary adenomas. European Journal of Endocrinology 147 263-268. (https:// doi.org/10.1530/eje.0.1470263)

Beech SG, Walker SW, Arthur JR, Lee D \& Beckett GJ 1995 Differential control of type-I iodothyronine deiodinase expression by the activation of the cyclic AMP and phosphoinositol signalling pathways in cultured human thyrocytes. Journal of Molecular Endocrinology 14 171-177. (https://doi.org/10.1677/jme.0.0140171)

Berry MJ, Kates AL \& Larsen PR 1990 Thyroid hormone regulates type I deiodinase messenger RNA in rat liver. Molecular Endocrinology 4 743-748. (https://doi.org/10.1210/mend-4-5-743)

Berry MJ, Banu L, Chen YY, Mandel SJ, Kieffer JD, Harney JW \& Larsen PR 1991a Recognition of UGA as a selenocysteine codon in type I deiodinase requires sequences in the $3^{\prime}$ untranslated region. Nature 353 273-276. (https://doi.org/10.1038/353273a0)

Berry MJ, Banu L \& Larsen PR 1991b Type I iodothyronine deiodinase is a selenocysteine-containing enzyme. Nature 349 438-440. (https:// doi.org/10.1038/349438a0)

Bianco AC 2011 Minireview: cracking the metabolic code for thyroid hormone signaling. Endocrinology 152 3306-3311. (https://doi. org/10.1210/en.2011-1104)

Bianco AC \& Kim BW 2006 Deiodinases: implications of the local control of thyroid hormone action. Journal of Clinical Investigation 116 2571-2579. (https://doi.org/10.1172/JCI29812)

Bianco AC, Kieffer JD \& Silva JE 1992 Adenosine 3',5'-monophosphate and thyroid hormone control of uncoupling protein messenger ribonucleic acid in freshly dispersed brown adipocytes. Endocrinology 130 2625-2633. (https://doi.org/10.1210/endo.130.5.1374009)

Boelen A, Kwakkel J, Platvoet-ter Schiphorst M, Baur A, Kohrle J \& Wiersinga WM 2004 Contribution of interleukin-12 to the pathogenesis of non-thyroidal illness. Hormone and Metabolic Research 36 101-106. (https://doi.org/10.1055/s-2004-814219)

Boguslawska J, Wojcicka A, Piekielko-Witkowska A, Master A \& Nauman A 2011 MiR-224 targets the 3'UTR of type 1 5 '-iodothyronine deiodinase possibly contributing to tissue hypothyroidism in renal cancer. PLOS ONE 6 e24541. (https://doi. org/10.1371/journal.pone.0024541)

Boye E, Yu Y, Paranya G, Mulliken JB, Olsen BR \& Bischoff J 2001 Clonality and altered behavior of endothelial cells from hemangiomas. Journal of Clinical Investigation 107 745-752.

Braverman LE, Ingbar SH \& Sterling K 1970 Conversion of thyroxine (T4) to triiodothyronine (T3) in athyreotic human subjects. Journal of Clinical Investigation 49 855-864. (https://doi.org/10.1172/ JCI106304)

Brtko J, Bobalova J, Podoba J, Schmutzler C \& Kohrle J 2002 Thyroid hormone receptors and type I iodothyronine 5 '-deiodinase activity of human thyroid toxic adenomas and benign cold nodules. Experimental and Clinical Endocrinology and Diabetes 110 166-170. (https://doi.org/10.1055/s-2002-32147)

Burmeister LA, Pachucki J \& St Germain DL 1997 Thyroid hormones inhibit type 2 iodothyronine deiodinase in the rat cerebral cortex by both pre- and posttranslational mechanisms. Endocrinology 138 5231-5237. (https://doi.org/10.1210/endo.138.12.5602)

Campos-Barros A, Hoell T, Musa A, Sampaolo S, Stoltenburg G, Pinna G, Eravci M, Meinhold H \& Baumgartner A 1996 Phenolic and tyrosyl ring iodothyronine deiodination and thyroid hormone concentrations in the human central nervous system. Journal of
Clinical Endocrinology and Metabolism 81 2179-2185. (https://doi. org/10.1210/jcem.81.6.8964848)

Cancer Genome Atlas Research Network 2014 Integrated genomic characterization of papillary thyroid carcinoma. Cell 159 676-690. (https://doi.org/10.1016/j.cell.2014.09.050)

Casula S \& Bianco AC 2012 Thyroid hormone deiodinases and cancer. Frontiers in Endocrinology 3 74. (https://doi.org/10.3389/ fendo.2012.00074)

Catalano V, Dentice M, Ambrosio R, Luongo C, Carollo R, Benfante A, Todaro M, Stassi G \& Salvatore D 2016 Activated thyroid hormone promotes differentiation and chemotherapeutic sensitization of colorectal cancer stem cells by regulating Wnt and BMP4 signaling. Cancer Research 76 1237-1244. (https://doi.org/10.1158/0008-5472. CAN-15-1542)

Cestari SH, Figueiredo NB, Conde SJ, Clara S, Katayama ML, Padovani CR, Brentani MM \& Nogueira CR 2009 Influence of estradiol and triiodothyronine on breast cancer cell lines proliferation and expression of estrogen and thyroid hormone receptors. Arquivos Brasileiros de Endocrinologia and Metabologia 53 859-864. (https://doi.org/10.1590/S0004-27302009000700010)

Chakravarty D, Santos E, Ryder M, Knauf JA, Liao XH, West BL, Bollag G, Kolesnick R, Thin TH, Rosen N, et al. 2011 Small-molecule MAPK inhibitors restore radioiodine incorporation in mouse thyroid cancers with conditional BRAF activation. Journal of Clinical Investigation 121 4700-4711. (https://doi.org/10.1172/JCI46382)

Chambers SM, Fasano CA, Papapetrou EP, Tomishima M, Sadelain M \& Studer L 2009 Highly efficient neural conversion of human ES and iPS cells by dual inhibition of SMAD signaling. Nature Biotechnology 27 275-280. (https://doi.org/10.1038/nbt.1529)

Chen RN, Huang YH, Lin YC, Yeh CT, Liang Y, Chen SL \& Lin KH 2008 Thyroid hormone promotes cell invasion through activation of furin expression in human hepatoma cell lines. Endocrinology 149 3817-3831. (https://doi.org/10.1210/en.2007-0989)

Chen TS, Eichenfield LF \& Friedlander SF 2013 Infantile hemangiomas: an update on pathogenesis and therapy. Pediatrics 131 99-108.

Chen CY, Chung IH, Tsai MM, Tseng YH, Chi HC, Tsai CY, Lin YH, Wang YC, Chen CP, Wu TI, et al. 2014 Thyroid hormone enhanced human hepatoma cell motility involves brain-specific serine protease 4 activation via ERK signaling. Molecular Cancer 13 162. (https://doi. org/10.1186/1476-4598-13-162)

Chen K, Yan B, Wang F, Wen F, Xing X, Tang X, Shi Y \& Le G 2016 Type 15 -deiodinase activity is inhibited by oxidative stress and restored by alpha-lipoic acid in HepG2 cells. Biochemical and Biophysical Research Communications 472 496-501. (https://doi. org/10.1016/j.bbrc.2016.02.119)

Christoffolete MA, Doleschall M, Egri P, Liposits Z, Zavacki AM, Bianco AC \& Gereben B 2010 Regulation of thyroid hormone activation via the liver X-receptor/retinoid X-receptor pathway. Journal of Endocrinology 205 179-186. (https://doi.org/10.1677/JOE09-0448)

Ciavardelli D, Bellomo M, Crescimanno C \& Vella V 2014 Type 3 deiodinase: role in cancer growth, stemness, and metabolism. Frontiers in Endocrinology 5 215. (https://doi.org/10.3389/ fendo.2014.00215)

Consortium GT 2013 The Genotype-Tissue Expression (GTEx) project. Nature Genetics 45 580-585. (https://doi.org/10.1038/ng.2653)

Crantz FR \& Larsen PR 1980 Rapid thyroxine to 3,5,3'-triiodothyronine conversion and nuclear 3,5,3'-triiodothyronine binding in rat cerebral cortex and cerebellum. Journal of Clinical Investigation $\mathbf{6 5}$ 935-938. (https://doi.org/10.1172/JCI109749)

Crantz FR, Silva JE \& Larsen PR 1982 An analysis of the sources and quantity of 3,5,3'-triiodothyronine specifically bound to nuclear receptors in rat cerebral cortex and cerebellum. Endocrinology 110 367-375. (https://doi.org/10.1210/endo-110-2-367)

Crespo M, Vilar E, Tsai SY, Chang K, Amin S, Srinivasan T, Zhang T, Pipalia NH, Chen HJ, Witherspoon M, et al. 2017 Colonic organoids
(C) 2019 Society for Endocrinology Published by Bioscientifica Ltd. Printed in Great Britain 
derived from human induced pluripotent stem cells for modeling colorectal cancer and drug testing. Nature Medicine 23 878-884. (https://doi.org/10.1038/nm.4355)

Croteau W, Davey JC, Galton VA \& St Germain DL 1996 Cloning of the mammalian type II iodothyronine deiodinase. A selenoprotein differentially expressed and regulated in human and rat brain and other tissues. Journal of Clinical Investigation 98 405-417. (https://doi. org/10.1172/JCI118806)

Curcio-Morelli C, Gereben B, Zavacki AM, Kim BW, Huang S, Harney JW, Larsen PR \& Bianco AC 2003a In vivo dimerization of types 1, 2, and 3 iodothyronine selenodeiodinases. Endocrinology $\mathbf{1 4 4}$ 937-946. (https://doi.org/10.1210/en.2002-220960)

Curcio-Morelli C, Zavacki AM, Christofollete M, Gereben B, de Freitas BC, Harney JW, Li Z, Wu G \& Bianco AC 2003b Deubiquitination of type 2 iodothyronine deiodinase by von HippelLindau protein-interacting deubiquitinating enzymes regulates thyroid hormone activation. Journal of Clinical Investigation 112 189-196. (https://doi.org/10.1172/JCI18348)

Darras VM, Visser TJ, Berghman LR \& Kuhn ER 1992 Ontogeny of type I and type III deiodinase activities in embryonic and posthatch chicks: relationship with changes in plasma triiodothyronine and growth hormone levels. Comparative Biochemistry and Physiology 103 131-136. (https://doi.org/10.1016/0300-9629(92)90252-L)

Davies PH, Sheppard MC \& Franklyn JA 1997 Inflammatory cytokines and type I 5'-deiodinase expression in phi1 rat liver cells. Molecular and Cellular Endocrinology 129 191-198. (https://doi.org/10.1016/ S0303-7207(97)04058-6)

Davis PJ, Goglia F \& Leonard JL 2016 Nongenomic actions of thyroid hormone. Nature Reviews Endocrinology 12 111-121. (https://doi. org/10.1038/nrendo.2015.205)

de Jesus LA, Carvalho SD, Ribeiro MO, Schneider M, Kim SW, Harney JW, Larsen PR \& Bianco AC 2001 The type 2 iodothyronine deiodinase is essential for adaptive thermogenesis in brown adipose tissue. Journal of Clinical Investigation 108 1379-1385. (https://doi. org/10.1172/JCI200113803)

de Jong M, Visser TJ, Bernard BF, Docter R, Vos RA, Hennemann G \& Krenning EP 1993 Transport and metabolism of iodothyronines in cultured human hepatocytes. Journal of Clinical Endocrinology and Metabolism 77 139-143. (https://doi.org/10.1210/jcem.77.1.8392080)

De Sibio MT, de Oliveira M, Moretto FC, Olimpio RM, Conde SJ, Luvizon AC \& Nogueira CR 2014 Triiodothyronine and breast cancer. World Journal of Clinical Oncology 5 503-508. (https://doi. org/10.5306/wjco.v5.i3.503)

de Souza Meyer EL, Dora JM, Wagner MS \& Maia AL 2005 Decreased type 1 iodothyronine deiodinase expression might be an early and discrete event in thyroid cell dedifferentation towards papillary carcinoma. Clinical Endocrinology 62 672-678. (https://doi. org/10.1111/j.1365-2265.2005.02277.x)

Debski MG, Pachucki J, Ambroziak M, Olszewski W \& Bar-Andziak E 2007 Human breast cancer tissue expresses high level of type 1 5'-deiodinase. Thyroid 17 3-10. (https://doi.org/10.1089/ thy.2006.0012)

Dentice M, Antonini D \& Salvatore D 2013 Type 3 deiodinase and solid tumors: an intriguing pair. Expert Opinion on Therapeutic Targets 17 1369-1379. (https://doi.org/10.1517/14728222.2013.833189)

Dentice M, Bandyopadhyay A, Gereben B, Callebaut I, Christoffolete MA, Kim BW, Nissim S, Mornon JP, Zavacki AM, Zeold A, et al. 2005 The Hedgehog-inducible ubiquitin ligase subunit WSB-1 modulates thyroid hormone activation and PTHrP secretion in the developing growth plate. Nature Cell Biology 7 698-705. (https://doi.org/10.1038/ncb1272)

Dentice M, Luongo C, Ambrosio R, Sibilio A, Casillo A, Iaccarino A, Troncone G, Fenzi G, Larsen PR \& Salvatore D 2012 beta-Catenin regulates deiodinase levels and thyroid hormone signaling in colon cancer cells. Gastroenterology 143 1037-1047. (https://doi. org/10.1053/j.gastro.2012.06.042)
Dentice M, Luongo C, Huang S, Ambrosio R, Elefante A, MirebeauPrunier D, Zavacki AM, Fenzi G, Grachtchouk M, Hutchin M, et al. 2007 Sonic hedgehog-induced type 3 deiodinase blocks thyroid hormone action enhancing proliferation of normal and malignant keratinocytes. PNAS 104 14466-14471. (https://doi.org/10.1073/ pnas.0706754104)

Dentice M, Marsili A, Ambrosio R, Guardiola O, Sibilio A, Paik JH, Minchiotti G, DePinho RA, Fenzi G, Larsen PR, et al. 2010 The FoxO3/type 2 deiodinase pathway is required for normal mouse myogenesis and muscle regeneration. Journal of Clinical Investigation 120 4021-4030. (https://doi.org/10.1172/JCI43670)

Dentice M, Morisco C, Vitale M, Rossi G, Fenzi G \& Salvatore D 2003 The different cardiac expression of the type 2 iodothyronine deiodinase gene between human and rat is related to the differential response of the Dio2 genes to Nkx-2.5 and GATA-4 transcription factors. Molecular Endocrinology 17 1508-1521. (https://doi. org/10.1210/me.2002-0348)

Di Girolamo D, Ambrosio R, De Stefano MA, Mancino G, Porcelli T, Luongo C, Di Cicco E, Scalia G, Vecchio LD, Colao A, et al. 2016 Reciprocal interplay between thyroid hormone and microRNA-21 regulates hedgehog pathway-driven skin tumorigenesis. Journal of Clinical Investigation 126 2308-2320. (https://doi.org/10.1172/ JCI84465)

Dow LE \& Lowe SW 2012 Life in the fast lane: mammalian disease models in the genomics era. Cell 148 1099-1109. (https://doi. org/10.1016/j.cell.2012.02.023)

Dudek KM, Suter L, Darras VM, Marczylo EL \& Gant TW 2013 Decreased translation of Dio3 mRNA is associated with drug-induced hepatotoxicity. Biochemical Journal 453 71-82. (https://doi. org/10.1042/BJ20130049)

Epstein EH 2008 Basal cell carcinomas: attack of the hedgehog. Nature Reviews Cancer 8 743-754. (https://doi.org/10.1038/nrc2503)

Farwell AP, Dubord-Tomasetti SA, Pietrzykowski AZ, Stachelek SJ \& Leonard JL 2005 Regulation of cerebellar neuronal migration and neurite outgrowth by thyroxine and 3,3',5'-triiodothyronine. Brain Research Developmental Brain Research 154 121-135. (https://doi. org/10.1016/j.devbrainres.2004.07.016)

Fekete C, Gereben B, Doleschall M, Harney JW, Dora JM, Bianco AC, Sarkar S, Liposits Z, Rand W, Emerson C, et al. 2004 Lipopolysaccharide induces type 2 iodothyronine deiodinase in the mediobasal hypothalamus: implications for the nonthyroidal illness syndrome. Endocrinology 145 1649-1655. (https://doi.org/10.1210/ en.2003-1439)

Fekkes D, Hennemann G \& Visser TJ 1982 Evidence for a single enzyme in rat liver catalysing the deiodination of the tyrosyl and the phenolic ring of iodothyronines. Biochemical Journal 201 673-676. (https://doi.org/10.1042/bj2010673)

Frese KK \& Tuveson DA 2007 Maximizing mouse cancer models. Nature Reviews Cancer 7 645-658. (https://doi.org/10.1038/nrc2192)

Friesema EC, Kuiper GG, Jansen J, Visser TJ \& Kester MH 2006 Thyroid hormone transport by the human monocarboxylate transporter 8 and its rate-limiting role in intracellular metabolism. Molecular Endocrinology 20 2761-2772. (https://doi.org/10.1210/me.20050256)

Funato K, Major T, Lewis PW, Allis CD \& Tabar V 2014 Use of human embryonic stem cells to model pediatric gliomas with H3.3K27M histone mutation. Science 346 1529-1533. (https://doi.org/10.1126/ science.1253799)

Garcia-Solis P \& Aceves C 2003 5'Deiodinase in two breast cancer cell lines: effect of triiodothyronine, isoproterenol and retinoids. Molecular and Cellular Endocrinology 201 25-31. (https://doi. org/10.1016/S0303-7207(03)00007-8)

Garcia-Silva S \& Aranda A 2004 The thyroid hormone receptor is a suppressor of ras-mediated transcription, proliferation, and transformation. Molecular and Cellular Biology 24 7514-7523. (https:// doi.org/10.1128/MCB.24.17.7514-7523.2004)
(C) 2019 Society for Endocrinology Published by Bioscientifica Ltd. Printed in Great Britain 
Gereben B, Zavacki AM, Ribich S, Kim BW, Huang SA, Simonides WS, Zeold A \& Bianco AC 2008 Cellular and molecular basis of deiodinase-regulated thyroid hormone signaling. Endocrine Reviews 29 898-938. (https://doi.org/10.1210/er.2008-0019)

Goemann IM, Romitti M, Meyer ELS, Wajner SM \& Maia AL 2017 Role of thyroid hormones in the neoplastic process: an overview. Endocrine-Related Cancer 24 R367-R385. (https://doi.org/10.1530/ ERC-17-0192)

Gouveia CH, Christoffolete MA, Zaitune CR, Dora JM, Harney JW, Maia AL \& Bianco AC 2005 Type 2 iodothyronine selenodeiodinase is expressed throughout the mouse skeleton and in the MC3T3-E1 mouse osteoblastic cell line during differentiation. Endocrinology 146 195-200. (https://doi.org/10.1210/en.2004-1043)

Gross J \& Pitt-Rivers R 1952 The identification of 3:5:3'-L-triiodothyronine in human plasma. Lancet 1 439-441. (https://doi.org/10.1016/S0140-6736(52)91952-1)

Grozovsky R, Ribich S, Rosene ML, Mulcahey MA, Huang SA, Patti ME, Bianco AC \& Kim BW 2009 Type 2 deiodinase expression is induced by peroxisomal proliferator-activated receptor-gamma agonists in skeletal myocytes. Endocrinology 150 1976-1983. (https://doi. org/10.1210/en.2008-0938)

Hall LC, Salazar EP, Kane SR \& Liu N 2008 Effects of thyroid hormones on human breast cancer cell proliferation. Journal of Steroid Biochemistry and Molecular Biology 109 57-66. (https://doi. org/10.1016/j.jsbmb.2007.12.008)

Hardy JJ, Thomas CL \& Utiger RD 1986 Characteristics of thyroxine 5 '-deiodinase activity in human liver. American Journal of the Medical Sciences 292 193-197. (https://doi.org/10.1097/00000441-19861000000002)

Hassan MM, Kaseb A, Li D, Patt YZ, Vauthey JN, Thomas MB, Curley SA, Spitz MR, Sherman SI, Abdalla EK, et al. 2009 Association between hypothyroidism and hepatocellular carcinoma: a case-control study in the United States. Hepatology 49 1563-1570. (https://doi. org/10.1002/hep.22793)

Haugen BR, Alexander EK, Bible KC, Doherty GM, Mandel SJ, Nikiforov YE, Pacini F, Randolph GW, Sawka AM, Schlumberger M, et al. 20162015 American Thyroid Association management guidelines for adult patients with thyroid nodules and differentiated thyroid cancer: the American Thyroid Association guidelines task force on thyroid nodules and differentiated thyroid cancer. Thyroid 26 1-133. (https://doi.org/10.1089/thy.2015.0020)

Hercbergs AA, Goyal LK, Suh JH, Lee S, Reddy CA, Cohen BH, Stevens GH, Reddy SK, Peereboom DM, Elson PJ, et al. 2003 Propylthiouracil-induced chemical hypothyroidism with high-dose tamoxifen prolongs survival in recurrent high grade glioma: a phase I/II study. Anticancer Research 23 617-626.

Hilf R, Michel I \& Bell C 1967 Biochemical and morphological responses of normal and neoplastic mammary tissue to hormonal treatment. Recent Progress in Hormone Research 23 229-295.

Hosoi Y, Murakami M, Mizuma H, Ogiwara T, Imamura M \& Mori M 1999 Expression and regulation of type II iodothyronine deiodinase in cultured human skeletal muscle cells. Journal of Clinical Endocrinology and Metabolism 84 3293-3300. (https://doi. org/10.1210/jcem.84.9.5969)

Huang SA 2005 Physiology and pathophysiology of type 3 deiodinase in humans. Thyroid 15 875-881. (https://doi.org/10.1089/ thy.2005.15.875)

Huang SA, Tu HM, Harney JW, Venihaki M, Butte AJ, Kozakewich HP, Fishman SJ \& Larsen PR 2000 Severe hypothyroidism caused by type 3 iodothyronine deiodinase in infantile hemangiomas. New England Journal of Medicine 343 185-189.

Huang Y, Prasad M, Lemon WJ, Hampel H, Wright FA, Kornacker K, LiVolsi V, Frankel W, Kloos RT, Eng C, et al. 2001 Gene expression in papillary thyroid carcinoma reveals highly consistent profiles. PNAS 98 15044-15049. (https://doi.org/10.1073/pnas.251547398)
Huang SA, Fish SA, Dorfman DM, Salvatore D, Kozakewich HP, Mandel SJ \& Larsen PR 2002 A 21-year-old woman with consumptive hypothyroidism due to a vascular tumor expressing type 3 iodothyronine deiodinase. Journal of Clinical Endocrinology and Metabolism 87 4457-4461.

Huang SA, Dorfman DM, Genest DR, Salvatore D \& Larsen PR 2003 Type 3 iodothyronine deiodinase is highly expressed in the human uteroplacental unit and in fetal epithelium. Journal of Clinical Endocrinology and Metabolism 88 1384-1388. (https://doi. org/10.1210/jc.2002-021291)

Huang SA, Mulcahey MA, Crescenzi A, Chung M, Kim BW, Barnes C, Kuijt W, Turano H, Harney J \& Larsen PR 2005 Transforming growth factor-beta promotes inactivation of extracellular thyroid hormones via transcriptional stimulation of type 3 iodothyronine deiodinase. Molecular Endocrinology 19 3126-3136. (https://doi.org/10.1210/ me.2005-0173)

Huijbers IJ, Krimpenfort P, Berns A \& Jonkers J 2011 Rapid validation of cancer genes in chimeras derived from established genetically engineered mouse models. Bioessays 33 701-710. (https://doi. org/10.1002/bies.201100018)

Ingham PW \& McMahon AP 2001 Hedgehog signaling in animal development: paradigms and principles. Genes and Development 15 3059-3087. (https://doi.org/10.1101/gad.938601)

Ishii H, Inada M, Tanaka K, Mashio Y, Naito K, Nishikawa M \& Imura H 1981 Triiodothyronine generation from thyroxine in human thyroid: enhanced conversion in Graves' thyroid tissue. Journal of Clinical Endocrinology and Metabolism 52 1211-1217. (https://doi. org/10.1210/jcem-52-6-1211)

Ishii H, Inada M, Tanaka K, Mashio Y, Naito K, Nishikawa M, Matsuzuka F, Kuma K \& Imura H 1982 Sequential deiodination of thyroxine in human thyroid gland. Journal of Clinical Endocrinology and Metabolism 55 890-896. (https://doi.org/10.1210/jcem-55-5-890)

Ishii H, Inada M, Tanaka K, Mashio Y, Naito K, Nishikawa M, Matsuzuka F, Kuma K \& Imura H 1983 Induction of outer and inner ring monodeiodinases in human thyroid gland by thyrotropin. Journal of Clinical Endocrinology and Metabolism 57 500-505. (https:// doi.org/10.1210/jcem-57-3-500)

Jakobs TC, Schmutzler C, Meissner J \& Kohrle J 1997 The promoter of the human type I 5'-deiodinase gene - mapping of the transcription start site and identification of a DR+4 thyroid-hormone-responsive element. European Journal of Biochemistry 247 288-297. (https://doi. org/10.1111/j.1432-1033.1997.00288.x)

Jakobs TC, Mentrup B, Schmutzler C, Dreher I \& Kohrle J 2002 Proinflammatory cytokines inhibit the expression and function of human type I 5'-deiodinase in HepG2 hepatocarcinoma cells. European Journal of Endocrinology 146 559-566. (https://doi. org/10.1530/eje.0.1460559)

Jansen J, Friesema EC, Milici C \& Visser TJ 2005 Thyroid hormone transporters in health and disease. Thyroid 15 757-768. (https://doi. org/10.1089/thy.2005.15.757)

Kanamoto N, Tagami T, Ueda-Sakane Y, Sone M, Miura M, Yasoda A, Tamura N, Arai H \& Nakao K 2012 Forkhead box A1 (FOXA1) and A2 (FOXA2) oppositely regulate human type 1 iodothyronine deiodinase gene in liver. Endocrinology 153 492-500. (https://doi. org/10.1210/en.2011-1310)

Kaplan MM, Visser TJ, Yaskoski KA \& Leonard JL 1983 Characteristics of iodothyronine tyrosyl ring deiodination by rat cerebral cortical microsomes. Endocrinology 112 35-42. (https://doi.org/10.1210/endo112-1-35)

Kaplan MM, Pan CY, Gordon PR, Lee JK \& Gilchrest BA 1988 Human epidermal keratinocytes in culture convert thyroxine to 3,5,3'-triiodothyronine by type II iodothyronine deiodination: a novel endocrine function of the skin. Journal of Clinical Endocrinology and Metabolism 66 815-822. (https://doi.org/10.1210/ jcem-66-4-815)
(2) 2019 Society for Endocrinology Published by Bioscientifica Ltd. Printed in Great Britain 
Kester MH, Martinez de Mena R, Obregon MJ, Marinkovic D, Howatson A, Visser TJ, Hume R \& Morreale de Escobar G 2004 Iodothyronine levels in the human developing brain: major regulatory roles of iodothyronine deiodinases in different areas. Journal of Clinical Endocrinology and Metabolism 89 3117-3128. (https://doi.org/10.1210/jc.2003-031832)

Kester MH, Kuiper GG, Versteeg R \& Visser TJ 2006 Regulation of type III iodothyronine deiodinase expression in human cell lines. Endocrinology 147 5845-5854. (https://doi.org/10.1210/en.20060590)

Kim BW, Daniels GH, Harrison BJ, Price A, Harney JW, Larsen PR \& Weetman AP 2003 Overexpression of type 2 iodothyronine deiodinase in follicular carcinoma as a cause of low circulating free thyroxine levels. Journal of Clinical Endocrinology and Metabolism $\mathbf{8 8}$ 594-598. (https://doi.org/10.1210/jc.2002-020921)

Köhrle J, Oertel M, Hoang-Vu C, Schnieders F \& Brabant G 1993 Type I 5 '-deiodinase a marker for differentiated thyroid carcinoma? Experimental and Clinical Endocrinology and Diabetes 101 60-72.

Koopdonk-Kool JM, de Vijlder JJ, Veenboer GJ, Ris-Stalpers C, Kok JH, Vulsma T, Boer K \& Visser TJ 1996 Type II and type III deiodinase activity in human placenta as a function of gestational age. Journal of Clinical Endocrinology and Metabolism 81 2154-2158. (https://doi. org/10.1210/jcem.81.6.8964844)

Koppenol WH, Bounds PL \& Dang CV 2011 Otto Warburg's contributions to current concepts of cancer metabolism. Nature Reviews Cancer 11 325-337. (https://doi.org/10.1038/nrc3038)

Kornasiewicz O, Debski M, Stepnowska M, Szalas A, Bar-Andziak E \& Krawczyk M 2010 The enzymatic activity of type 1 iodothyronine deiodinase (D1) is low in liver hemangioma: a preliminary study. Archivum Immunologiae et Therapia Experimentalis 58 77-80. (https:// doi.org/10.1007/s00005-009-0056-3)

Kornasiewicz O, Debski M, Grat M, Lenartowicz B, Stepnowska M, Szalas A, Bar-Andziak E \& Krawczyk M 2014 Enzymatic activity of type 1 iodothyronine deiodinase in selected liver tumors. Archives of Medical Science 10 801-805. (https://doi.org/10.5114/ aoms.2013.34323)

Kosti I, Jain N, Aran D, Butte AJ \& Sirota M 2016 Cross-tissue analysis of gene and protein expression in normal and cancer tissues. Scientific Reports 6 24799. (https://doi.org/10.1038/srep24799)

Kurmann AA, Serra M, Hawkins F, Rankin SA, Mori M, Astapova I, Ullas S, Lin S, Bilodeau M, Rossant J, et al. 2015 Regeneration of thyroid function by transplantation of differentiated pluripotent stem cells. Cell Stem Cell 17 527-542. (https://doi.org/10.1016/j. stem.2015.09.004)

Lam EW \& Gomes AR 2014 Forkhead box transcription factors in cancer initiation, progression and chemotherapeutic drug response. Frontiers in Oncology 4 305. (https://doi.org/10.3389/fonc.2014.00305)

Lartey LJ, Werneck-de-Castro JP, InSug O, Unterman TG \& Bianco AC 2015 Coupling between nutrient availability and thyroid hormone activation. Journal of Biological Chemistry 290 30551-30561. (https:// doi.org/10.1074/jbc.M115.665505)

Lehnen TE, Santos MV, Lima A, Maia AL \& Wajner SM 2017 $\mathrm{N}$-acetylcysteine prevents low T3 syndrome and attenuates cardiac dysfunction in a male rat model of myocardial infarction. Endocrinology 158 1502-1510. (https://doi.org/10.1210/en.2016-1586)

Leonard JL \& Rosenberg IN 1978 Thyroxine 5'-deiodinase activity of rat kidney: observations on activation by thiols and inhibition by propylthiouracil. Endocrinology 103 2137-2144. (https://doi. org/10.1210/endo-103-6-2137)

Liappas A, Mourouzis I, Zisakis A, Economou K, Lea RW \& Pantos C 2011 Cell-type-dependent thyroid hormone effects on glioma tumor cell lines. Journal of Thyroid Research 2011 856050. (https://doi. org/10.4061/2011/856050)

Louis DN, Perry A, Reifenberger G, von Deimling A, Figarella-Branger D, Cavenee WK, Ohgaki H, Wiestler OD, Kleihues P \& Ellison DW 2016 The 2016 World Health Organization classification of tumors of the central nervous system: a summary. Acta Neuropathologica 131 803-820. (https://doi.org/10.1007/s00401-016-1545-1)

Luk JM, Burchard J, Zhang C, Liu AM, Wong KF, Shek FH, Lee NP, Fan ST, Poon RT, Ivanovska I, et al. 2011 DLK1-DIO3 genomic imprinted microRNA cluster at 14q32.2 defines a stemlike subtype of hepatocellular carcinoma associated with poor survival. Journal of Biological Chemistry 286 30706-30713. (https://doi.org/10.1074/jbc. M111.229831)

Luongo C, Ambrosio R, Salzano S, Dlugosz AA, Missero C \& Dentice M 2014 The sonic hedgehog-induced type 3 deiodinase facilitates tumorigenesis of basal cell carcinoma by reducing Gli2 inactivation. Endocrinology 155 2077-2088. (https://doi.org/10.1210/en.2013-2108)

Maeda A, Toyoda N, Yasuzawa-Amano S, Iwasaka T \& Nishikawa M 2003 Type 2 deiodinase expression is stimulated by growth factors in human vascular smooth muscle cells. Molecular and Cellular Endocrinology 200 111-117. (https://doi.org/10.1016/S03037207(02)00409-4)

Maia AL, Berry MJ, Sabbag R, Harney JW \& Larsen PR $1995 a$ Structural and functional differences in the dio1 gene in mice with inherited type 1 deiodinase deficiency. Molecular Endocrinology 9 969-980. (https://doi.org/10.1210/mend.9.8.7476994)

Maia AL, Kieffer JD, Harney JW \& Larsen PR 1995b Effect of 3,5,3'-Triiodothyronine (T3) administration on dio1 gene expression and T3 metabolism in normal and type 1 deiodinase-deficient mice. Endocrinology 136 4842-4849. (https://doi.org/10.1210/ endo.136.11.7588215)

Maia AL, Kim BW, Huang SA, Harney JW \& Larsen PR 2005 Type 2 iodothyronine deiodinase is the major source of plasma T3 in euthyroid humans. Journal of Clinical Investigation 115 2524-2533. (https://doi.org/10.1172/JCI25083)

Maia AL, Goemann IM, Meyer EL \& Wajner SM 2011 Deiodinases: the balance of thyroid hormone: type 1 iodothyronine deiodinase in human physiology and disease. Journal of Endocrinology 209 283-297. (https://doi.org/10.1530/JOE-10-0481)

Mandel SJ, Berry MJ, Kieffer JD, Harney JW, Warne RL \& Larsen PR 1992 Cloning and in vitro expression of the human selenoprotein, type I iodothyronine deiodinase. Journal of Clinical Endocrinology and Metabolism 75 1133-1139. (https://doi.org/10.1210/ jcem.75.4.1400883)

Markowitz SD \& Bertagnolli MM 2009 Molecular origins of cancer: Molecular basis of colorectal cancer. New England Journal of Medicine 361 2449-2460. (https://doi.org/10.1056/NEJMra0804588)

Martin-Subero JI, Ammerpohl O, Bibikova M, Wickham-Garcia E, Agirre X, Alvarez S, Bruggemann M, Bug S, Calasanz MJ, Deckert M, et al. 2009 A comprehensive microarray-based DNA methylation study of 367 hematological neoplasms. PLOS ONE 4 e6986. (https:// doi.org/10.1371/journal.pone.0006986)

Master A, Wojcicka A, Piekielko-Witkowska A, Boguslawska J, Poplawski P, Tanski Z, Darras VM, Williams GR \& Nauman A 2010 Untranslated regions of thyroid hormone receptor beta 1 mRNA are impaired in human clear cell renal cell carcinoma. Biochimica et Biophysica Acta 1802 995-1005. (https://doi.org/10.1016/j. bbadis.2010.07.025)

Matsunaga H, Sasaki S, Suzuki S, Matsushita A, Nakamura H, Nakamura HM, Hirahara N, Kuroda G, Iwaki H, Ohba K, et al. 2015 Essential role of GATA2 in the negative regulation of type 2 deiodinase gene by liganded thyroid hormone receptor beta2 in thyrotroph. PLOS ONE 10 e0142400. (https://doi.org/10.1371/ journal.pone.0142400)

Maynard MA, Marino-Enriquez A, Fletcher JA, Dorfman DM, Raut CP, Yassa L, Guo C, Wang Y, Dorfman C, Feldman HA, et al. 2014 Thyroid hormone inactivation in gastrointestinal stromal tumors. New England Journal of Medicine 370 1327-1334. (https://doi. org/10.1056/NEJMoa1308893)

Meyer EL, Wagner MS \& Maia AL 2007 Iodothyronine deiodinases expression in thyroid neoplasias. Arquivos Brasileiros de Endocrinologia
(2) 2019 Society for Endocrinology Published by Bioscientifica Ltd. Printed in Great Britain 
and Metabologia 51 690-700. (https://doi.org/10.1590/S000427302007000500006)

Meyer EL, Goemann IM, Dora JM, Wagner MS \& Maia AL 2008 Type 2 iodothyronine deiodinase is highly expressed in medullary thyroid carcinoma. Molecular and Cellular Endocrinology 289 16-22. (https:// doi.org/10.1016/j.mce.2008.04.009)

Miro C, Ambrosio R, De Stefano MA, Di Girolamo D, Di Cicco E, Cicatiello AG, Mancino G, Porcelli T, Raia M, Del Vecchio L, et al. 2017 The concerted action of type 2 and type 3 deiodinases regulates the cell cycle and survival of basal cell carcinoma cells. Thyroid 27 567-576. (https://doi.org/10.1089/thy.2016.0532)

Molina-Pinelo S, Salinas A, Moreno-Mata N, Ferrer I, Suarez R, AndresLeon E, Rodriguez-Paredes M, Gutekunst J, Jantus-Lewintre E, Camps C, et al. 2018 Impact of DLK1-DIO3 imprinted cluster hypomethylation in smoker patients with lung cancer. Oncotarget 9 4395-4410. (https://doi.org/10.18632/oncotarget.10611)

Mori K, Yoshida K, Kayama T, Kaise N, Fukazawa H, Kiso Y, Kikuchi K, Aizawa Y \& Abe K 1993 Thyroxine 5-deiodinase in human brain tumors. Journal of Clinical Endocrinology and Metabolism $\mathbf{7 7}$ 1198-1202. (https://doi.org/10.1210/jcem.77.5.8077312)

Murakami M, Araki O, Morimura T, Hosoi Y, Mizuma H, Yamada M, Kurihara H, Ishiuchi S, Tamura M, Sasaki T, et al. 2000 Expression of type II iodothyronine deiodinase in brain tumors. Journal of Clinical Endocrinology and Metabolism 85 4403-4406. (https://doi. org/10.1210/jcem.85.11.6952)

Murakami M, Araki O, Hosoi Y, Kamiya Y, Morimura T, Ogiwara T, Mizuma H \& Mori M 2001 Expression and regulation of type II iodothyronine deiodinase in human thyroid gland. Endocrinology 142 2961-2967. (https://doi.org/10.1210/endo.142.7.8280)

Nauman P, Bonicki W, Michalik R, Warzecha A \& Czernicki Z 2004 The concentration of thyroid hormones and activities of iodothyronine deiodinases are altered in human brain gliomas. Folia Neuropathologica 42 67-73.

Navarro L, Landa A, Valverde RC \& Aceves C 1997 Mammary gland type I iodothyronine deiodinase is encoded by a short messenger ribonucleic acid. Endocrinology 138 4248-4254. (https://doi. org/10.1210/endo.138.10.5393)

Nogueira CR \& Brentani MM 1996 Triiodothyronine mimics the effects of estrogen in breast cancer cell lines. Journal of Steroid Biochemistry and Molecular Biology 59 271-279. (https://doi.org/10.1016/S09600760(96)00117-3)

Ohguchi H, Tanaka T, Uchida A, Magoori K, Kudo H, Kim I, Daigo K, Sakakibara I, Okamura M, Harigae H, et al. 2008 Hepatocyte nuclear factor 4 alpha contributes to thyroid hormone homeostasis by cooperatively regulating the type 1 iodothyronine deiodinase gene with GATA4 and Kruppel-like transcription factor 9. Molecular and Cellular Biology 28 3917-3931. (https://doi.org/10.1128/ MCB.02154-07)

Ong ML, Kellen JA, Malkin DG \& Malkin A 1986 3,5,3'-Triiodothyronine (T3) and 3,3', $5^{\prime}$-triiodothyronine (rT3) synthesis in rats hosting the R3230AC mammary tumour. Tumor Biology 7 105-113.

Ongphiphadhanakul B, Fang SL, Tang KT, Patwardhan NA \& Braverman LE 1994 Tumor necrosis factor-alpha decreases thyrotropin-induced 5'-deiodinase activity in FRTL-5 thyroid cells. European Journal of Endocrinology 130 502-507. (https://doi. org/10.1530/eje.0.1300502)

Pachucki J, Ambroziak M, Tanski Z, Luczak J, Nauman J \& Nauman A 2001 Type I 5'-iodothyronine deiodinase activity and mRNA are remarkably reduced in renal clear cell carcinoma. Journal of Endocrinological Investigation 24 253-261. (https://doi.org/10.1007/ BF03343855)

Pallud S, Ramauge M, Gavaret JM, Lennon AM, Munsch N, St Germain DL, Pierre M \& Courtin F 1999 Regulation of type 3 iodothyronine deiodinase expression in cultured rat astrocytes: role of the Erk cascade. Endocrinology 140 2917-2923. (https://doi. org/10.1210/endo.140.6.6834)
Piekielko-Witkowska A \& Nauman A 2011 Iodothyronine deiodinases and cancer. Journal of Endocrinological Investigation 34 716-728. (https://doi.org/10.3275/7754)

Piekielko-Witkowska A, Master A, Wojcicka A, Boguslawska J, Brozda I, Tanski Z \& Nauman A 2009 Disturbed expression of type 1 iodothyronine deiodinase splice variants in human renal cancer. Thyroid 19 1105-1113. (https://doi.org/10.1089/thy.2008.0284)

Piekielko-Witkowska A, Wiszomirska H, Wojcicka A, Poplawski P, Boguslawska J, Tanski Z \& Nauman A 2010 Disturbed expression of splicing factors in renal cancer affects alternative splicing of apoptosis regulators, oncogenes, and tumor suppressors. PLOS ONE 5 e13690. (https://doi.org/10.1371/journal.pone.0013690)

Poplawski P \& Nauman A 2008 Thyroid hormone - triiodothyronine has contrary effect on proliferation of human proximal tubules cell line (HK2) and renal cancer cell lines (Caki-2, Caki-1) - role of E2F4, E2F5 and p107, p130. Thyroid Research 15.

Poplawski P, Rybicka B, Boguslawska J, Rodzik K, Visser TJ, Nauman A \& Piekielko-Witkowska A $2017 a$ Induction of type 1 iodothyronine deiodinase expression inhibits proliferation and migration of renal cancer cells. Molecular and Cellular Endocrinology 442 58-67. (https:// doi.org/10.1016/j.mce.2016.12.004)

Poplawski P, Wisniewski JR, Rijntjes E, Richards K, Rybicka B, Kohrle J \& Piekielko-Witkowska A $2017 b$ Restoration of type 1 iodothyronine deiodinase expression in renal cancer cells downregulates oncoproteins and affects key metabolic pathways as well as antioxidative system. PLOS ONE 12 e0190179. (https://doi.org/10.1371/ journal.pone.0190179)

Puzianowska-Kuznicka M, Nauman A, Madej A, Tanski Z, Cheng S \& Nauman J 2000 Expression of thyroid hormone receptors is disturbed in human renal clear cell carcinoma. Cancer Letters 155 145-152. (https://doi.org/10.1016/S0304-3835(00)00416-X)

Richard K, Hume R, Kaptein E, Sanders JP, van Toor H, De Herder WW, den Hollander JC, Krenning EP \& Visser TJ 1998 Ontogeny of iodothyronine deiodinases in human liver. Journal of Clinical Endocrinology and Metabolism 83 2868-2874. (https://doi. org/10.1210/jcem.83.8.5032)

Riskind PN, Kolodny JM \& Larsen PR 1987 The regional hypothalamic distribution of type II 5'-monodeiodinase in euthyroid and hypothyroid rats. Brain Research 420 194-198. (https://doi. org/10.1016/0006-8993(87)90260-5)

Romitti M, Wajner SM, Zennig N, Goemann IM, Bueno AL, Meyer EL \& Maia AL 2012 Increased type 3 deiodinase expression in papillary thyroid carcinoma. Thyroid 22 897-904. (https://doi.org/10.1089/ thy.2012.0031)

Romitti M, Wajner SM, Ceolin L, Ferreira CV, Ribeiro RV, Rohenkohl HC, de Weber S, Lopez PL, Fuziwara CS, Kimura ET, et al. 2016 MAPK and $\mathrm{SHH}$ pathways modulate type 3 deiodinase expression in papillary thyroid carcinoma. Endocrine-Related Cancer 23 135-146. (https://doi.org/10.1530/ERC-15-0162)

Rusolo F, Capone F, Pasquale R, Angiolillo A, Colonna G, Castello G, Costantini M \& Costantini S 2017 Comparison of the selenotranscriptome expression between human non-cancerous mammary epithelial cells and two human breast cancer cell lines. Oncology Letters 13 2411-2417. (https://doi.org/10.3892/ol.2017.5715)

Saberi M, Sterling FH \& Utiger RD 1975 Reduction in extrathyroidal triiodothyronine production by propylthiouracil in man. Journal of Clinical Investigation 55 218-223. (https://doi.org/10.1172/ JCI107924)

Saborowski M, Saborowski A, Morris JPt, Bosbach B, Dow LE, Pelletier J, Klimstra DS \& Lowe SW 2014 A modular and flexible ESC-based mouse model of pancreatic cancer. Genes and Development 28 85-97. (https://doi.org/10.1101/gad.232082.113)

Sagar GD, Gereben B, Callebaut I, Mornon JP, Zeold A, da Silva WS, Luongo C, Dentice M, Tente SM, Freitas BC, et al. 2007 Ubiquitination-induced conformational change within the deiodinase dimer is a switch regulating enzyme activity. Molecular (c) 2019 Society for Endocrinology Published by Bioscientifica Ltd. Printed in Great Britain 
and Cellular Biology 27 4774-4783. (https://doi.org/10.1128/ MCB.00283-07)

Sakurada T, Rudolph M, Fang SL, Vagenakis AG, Braverman LE \& Ingbar SH 1978 Evidence that triiodothyronine and reverse triiodothyronine are sequentially deiodinated in man. Journal of Clinical Endocrinology and Metabolism 46 916-922. (https://doi. org/10.1210/jcem-46-6-916)

Salvatore D, Low SC, Berry M, Maia AL, Harney JW, Croteau W, St Germain DL \& Larsen PR 1995 Type 3 lodothyronine deiodinase: cloning, in vitro expression, and functional analysis of the placental selenoenzyme. Journal of Clinical Investigation 96 2421-2430. (https:// doi.org/10.1172/JCI118299)

Salvatore D, Bartha T, Harney JW \& Larsen PR 1996a Molecular biological and biochemical characterization of the human type 2 selenodeiodinase. Endocrinology 137 3308-3315. (https://doi. org/10.1210/endo.137.8.8754756)

Salvatore D, Tu H, Harney JW \& Larsen PR 1996b Type 2 iodothyronine deiodinase is highly expressed in human thyroid. Journal of Clinical Investigation 98 962-968. (https://doi.org/10.1172/JCI118880)

Santini F, Vitti P, Chiovato L, Ceccarini G, Macchia M, Montanelli L, Gatti G, Rosellini V, Mammoli C, Martino E, et al. 2003 Role for inner ring deiodination preventing transcutaneous passage of thyroxine. Journal of Clinical Endocrinology and Metabolism $\mathbf{8 8}$ 2825-2830. (https://doi.org/10.1210/jc.2002-021439)

Schweizer U \& Steegborn C 2015 New insights into the structure and mechanism of iodothyronine deiodinases. Journal of Molecular Endocrinology 55 R37-R52. (https://doi.org/10.1530/JME-15-0156)

Schweizer U, Schlicker C, Braun D, Kohrle J \& Steegborn C 2014 Crystal structure of mammalian selenocysteine-dependent iodothyronine deiodinase suggests a peroxiredoxin-like catalytic mechanism. PNAS 111 10526-10531. (https://doi.org/10.1073/pnas.1323873111)

Sellheyer K 2011 Basal cell carcinoma: cell of origin, cancer stem cell hypothesis and stem cell markers. British Journal of Dermatology 164 696-711. (https://doi.org/10.1111/j.1365-2133.2010.10158.x)

Silva JE \& Leonard JL 1985 Regulation of rat cerebrocortical and adenohypophyseal type II 5'-deiodinase by thyroxine, triiodothyronine, and reverse triiodothyronine. Endocrinology 116 1627-1635. (https://doi.org/10.1210/endo-116-4-1627)

Simonides WS, Mulcahey MA, Redout EM, Muller A, Zuidwijk MJ, Visser TJ, Wassen FW, Crescenzi A, da-Silva WS, Harney J, et al. 2008 Hypoxia-inducible factor induces local thyroid hormone inactivation during hypoxic-ischemic disease in rats. Journal of Clinical Investigation 118 975-983. (https://doi.org/10.1172/JCI32824)

Slominski A, Wortsman J, Kohn L, Ain KB, Venkataraman GM, Pisarchik A, Chung JH, Giuliani C, Thornton M, Slugocki G, et al. 2002 Expression of hypothalamic-pituitary-thyroid axis related genes in the human skin. Journal of Investigative Dermatology 119 1449-1455. (https://doi.org/10.1046/j.1523-1747.2002.19617.x)

Song S \& Oka T 2003 Regulation of type II deiodinase expression by EGF and glucocorticoid in HC11 mouse mammary epithelium. American Journal of Physiology: Endocrinology and Metabolism 284 E1119-E1124.

Song S, Sorimachi K, Adachi K \& Oka T 2000 Biochemical and molecular biological evidence for the presence of type II iodothyronine deiodinase in mouse mammary gland. Molecular and Cellular Endocrinology 160 173-181. (https://doi.org/10.1016/S03037207(99)00249-X)

St Germain DL \& Morganelli CM 1989 Expression of type I iodothyronine $5^{\prime}$-deiodinase in Xenopus laevis oocytes. Journal of Biological Chemistry 264 3054-3056. (https://doi.org/10.1152/ ajpendo.00571.2002)

Steinsapir J, Bianco AC, Buettner C, Harney J \& Larsen PR 2000 Substrate-induced down-regulation of human type 2 deiodinase (hD2) is mediated through proteasomal degradation and requires interaction with the enzyme's active center. Endocrinology 141 1127-1135. (https://doi.org/10.1210/endo.141.3.7355)
Sterling K, Brenner MA \& Newman ES 1970 Conversion of thyroxine to triiodothyronine in normal human subjects. Science 169 1099-1100. (https://doi.org/10.1126/science.169.3950.1099)

Sugawara M, Lau R, Wasser HL, Nelson AM, Kuma K \& Hershman JM 1984 Thyroid T4 5'-deiodinase activity in normal and abnormal human thyroid glands. Metabolism 33 332-336. (https://doi. org/10.1016/0026-0495(84)90194-X)

Taipale J \& Beachy PA 2001 The Hedgehog and Wnt signalling pathways in cancer. Nature 411 349-354. (https://doi. org/10.1038/35077219)

Takano T, Miyauchi A, Ito Y \& Amino N 2006 Thyroxine to triiodothyronine hyperconversion thyrotoxicosis in patients with large metastases of follicular thyroid carcinoma. Thyroid 16 615-618. (https://doi.org/10.1089/thy.2006.16.615)

Tanaka K, Shimatsu A \& Imura H 1992 Iodothyronine 5-deiodinase in rat posterior pituitary. Biochemical and Biophysical Research Communications 188 272-277. (https://doi.org/10.1016/0006291X(92)92380-G)

Tang Z, Li C, Kang B, Gao G, Li C \& Zhang Z 2017 GEPIA: a web server for cancer and normal gene expression profiling and interactive analyses. Nucleic Acids Research 45 W98-W102. (https://doi. org/10.1093/nar/gkx247)

Tannahill LA, Visser TJ, McCabe CJ, Kachilele S, Boelaert K, Sheppard MC, Franklyn JA \& Gittoes NJ 2002 Dysregulation of iodothyronine deiodinase enzyme expression and function in human pituitary tumours. Clinical Endocrinology 56 735-743.

Toyoda N, Nishikawa M, Mori Y, Yoshimura M, Masaki H, Gondou A, Yonemoto T \& Inada M 1992 Identification of a 27-kilodalton protein with the properties of type I iodothyronine 5 '-deiodinase in human thyroid gland. Journal of Clinical Endocrinology and Metabolism 74 533-538. (https://doi.org/10.1210/jcem.74.3.1740487)

Toyoda N, Zavacki AM, Maia AL, Harney JW \& Larsen PR 1995 A novel retinoid $\mathrm{X}$ receptor-independent thyroid hormone response element is present in the human type 1 deiodinase gene. Molecular and Cellular Biology 15 5100-5112. (https://doi.org/10.1128/ MCB.15.9.5100)

Tu HM, Kim SW, Salvatore D, Bartha T, Legradi G, Larsen PR \& Lechan RM 1997 Regional distribution of type 2 thyroxine deiodinase messenger ribonucleic acid in rat hypothalamus and pituitary and its regulation by thyroid hormone. Endocrinology 138 3359-3368. (https://doi.org/10.1210/endo.138.8.5318)

Uhlen M, Fagerberg L, Hallstrom BM, Lindskog C, Oksvold P, Mardinoglu A, Sivertsson A, Kampf C, Sjostedt E, Asplund A, et al. 2015 Proteomics. Tissue-based map of the human proteome. Science 347 1260419. (https://doi.org/10.1126/science.1260419)

Van der Geyten S, Buys N, Sanders JP, Decuypere E, Visser TJ, Kuhn ER \& Darras VM 1999 Acute pretranslational regulation of type III iodothyronine deiodinase by growth hormone and dexamethasone in chicken embryos. Molecular and Cellular Endocrinology 147 49-56. (https://doi.org/10.1016/S0303-7207(98)00218-4)

van Stralen PG, van der Hoek HJ, Docter R, de Jong M, Krenning EP, Lim CF \& Hennemann G 1993 Reduced T3 deiodination by the human hepatoblastoma cell line HepG2 caused by deficient T3 sulfation. Biochimica et Biophysica Acta 1157 114-118. (https://doi. org/10.1016/0304-4165(93)90086-N)

van Stralen PG, van der Hoek HJ, Docter R, de Jong M, Krenning EP, Everts ME \& Hennemann G 1996 Uptake and metabolism of 3,5,3'-triiodothyronine and 3,3',5'-triiodothyronine by human liverderived cells: HepG2 cells as a model for thyroid hormone handling by human liver. Journal of Clinical Endocrinology and Metabolism $\mathbf{8 1}$ 244-248. (https://doi.org/10.1210/jcem.81.1.8550759)

Villavicencio EH, Walterhouse DO \& Iannaccone PM 2000 The sonic hedgehog-patched-gli pathway in human development and disease. American Journal of Human Genetics 67 1047-1054. (https://doi. org/10.1016/S0002-9297(07)62934-6)
(C) 2019 Society for Endocrinology Published by Bioscientifica Ltd. Printed in Great Britain 
Visser TJ 1979 Mechanism of action of iodothyronine-5'-deiodinase. Biochimica et Biophysica Acta 569 302-308. (https://doi. org/10.1016/0005-2744(79)90066-4)

Visser TJ \& Schoenmakers CH 1992 Characteristics of type III iodothyronine deiodinase. Acta Medica Austriaca 19 (Supplement 1) 18-21.

Visser TJ, Van der Does-Tobé I, Docter R \& Hennemann G 1975 Conversion of thyroxine into tri-iodothyronine by rat liver homogenate. Biochemical Journal 150 489-493. (https://doi.org/10.1042/bj1500489)

Visser TJ, Leonard JL, Kaplan MM \& Larsen PR 1981 Different pathways of iodothyronine 5'-deiodination in rat cerebral cortex. Biochemical and Biophysical Research Communications 101 1297-1304. (https://doi. org/10.1016/0006-291X(81)91588-6)

Vonderhaar BK \& Greco AE 1979 Lobulo-alveolar development of mouse mammary glands is regulated by thyroid hormones. Endocrinology 104 409-418. (https://doi.org/10.1210/endo-104-2-409)

Wajner SM, Goemann IM, Bueno AL, Larsen PR \& Maia AL 2011 IL-6 promotes nonthyroidal illness syndrome by blocking thyroxine activation while promoting thyroid hormone inactivation in human cells. Journal of Clinical Investigation 121 1834-1845. (https://doi. org/10.1172/JCI44678)

Wang T, Xia L, Ma S, Qi X, Li Q, Xia Y, Tang X, Cui D, Wang Z, Chi J, et al. 2016 Hepatocellular carcinoma: thyroid hormone promotes tumorigenicity through inducing cancer stem-like cell self-renewal. Scientific Reports 6 25183. (https://doi.org/10.1038/srep25183)
Wawrzynska L, Sakowicz A, Rudzinski P, Langfort R \& Kurzyna M 2003 The conversion of thyroxine to triiodothyronine in the lung: comparison of activity of type I iodothyronine $5^{\prime}$ deiodinase in lung cancer with peripheral lung tissues. Monaldi Archives for Chest Disease 59 140-145.

Weber Pasa M, Selbach Scheffel R, Borsatto Zanella A, Maia AL \& Dora JM 2017 Consumptive hypothyroidism: case report of hepatic hemangioendotheliomas successfully treated with vincristine and systematic review of the syndrome. European Thyroid Journal 6 321-327. (https://doi.org/10.1159/000481253)

Wu Y \& Koenig RJ 2000 Gene regulation by thyroid hormone. Trends in Endocrinology and Metabolism 11 207-211. (https://doi.org/10.1016/ S1043-2760(00)00263-0)

Wu SM, Cheng WL, Lin CD \& Lin KH 2013 Thyroid hormone actions in liver cancer. Cellular and Molecular Life Sciences 70 1915-1936. (https://doi.org/10.1007/s00018-012-1146-7)

Zhang CY, Kim S, Harney JW \& Larsen PR 1998 Further characterization of thyroid hormone response elements in the human type 1 iodothyronine deiodinase gene. Endocrinology 139 1156-1163. (https://doi.org/10.1210/endo.139.3.5849)

Zhu B, Shrivastava A, Luongo C, Chen T, Harney JW, Marsili A, Tran TV, Bhadouria A, Mopala R, Steen AI, et al. 2012 Catalysis leads to posttranslational inactivation of the type 1 deiodinase and alters its conformation. Journal of Endocrinology 214 87-94. (https://doi. org/10.1530/JOE-11-0459)

Received in final form 26 February 2018 Accepted 10 July 2018
(C) 2019 Society for Endocrinology Published by Bioscientifica Ltd. Printed in Great Britain 